Article

\title{
Application of Dynamic Controlled Atmosphere Technologies to Reduce Incidence of Physiological Disorders and Maintain Quality of 'Granny Smith' Apples
}

\author{
Tatenda Gift Kawhena ${ }^{1,2} \mathbb{D}$, Olaniyi Amos Fawole ${ }^{2,3} \mathbb{( D}$ and Umezuruike Linus Opara $2,4, * \mathbb{D}$ \\ 1 Department of Horticultural Science, Faculty of AgriSciences, Stellenbosch University, \\ Stellenbosch 7600, South Africa; 19547129@sun.ac.za \\ 2 SARChI Postharvest Technology Research Laboratory, Africa Institute for Postharvest Technology, \\ Faculty of AgriSciences, Stellenbosch University, Stellenbosch 7600, South Africa; olaniyi@sun.ac.za \\ 3 Postharvest Research Laboratory, Department of Botany and Plant Biotechnology, \\ University of Johannesburg, Johannesburg 2006, South Africa \\ 4 UNESCO International Centre for Biotechnology, Nsukka 410001, Enugu State, Nigeria \\ * Correspondence: opara@sun.ac.za; Tel.: +27-21-808-4068
}

check for updates

Citation: Kawhena, T.G.; Fawole, O.A.; Opara, U.L. Application of Dynamic Controlled Atmosphere Technologies to Reduce Incidence of Physiological Disorders and Maintain Quality of 'Granny Smith' Apples. Agriculture 2021, 11, 491. https://doi.org/10.3390/ agriculture11060491

Academic Editor: Dirk E. Maier

Received: 24 April 2021

Accepted: 18 May 2021

Published: 26 May 2021

Publisher's Note: MDPI stays neutral with regard to jurisdictional claims in published maps and institutional affiliations.

Copyright: (c) 2021 by the authors. Licensee MDPI, Basel, Switzerland. This article is an open access article distributed under the terms and conditions of the Creative Commons Attribution (CC BY) license (https:/ / creativecommons.org/licenses/by/ $4.0 /)$.

\begin{abstract}
The efficacy of dynamic controlled atmosphere technologies; repeated low oxygen stress (RLOS) and dynamic controlled atmosphere-chlorophyll fluorescence (DCA-CF) to control superficial scald development on 'Granny Smith' apples during long-term storage was studied. Fruit were stored for $2,4,6,8$, and 10 months at $0{ }^{\circ} \mathrm{C}$ in DCA-CF $\left(0.6 \% \mathrm{O}_{2}\right.$ and $\left.0.8 \% \mathrm{CO}_{2}\right)$, regular atmosphere (RA)( $\approx 21 \% \mathrm{O}_{2}$ and $90-95 \% \mathrm{RH}$ ), and RLOS treatments: (1) $0.5 \% \mathrm{O}_{2}$ for $10 \mathrm{~d}$ followed by ultra-low oxygen (ULO) $\left(0.9 \% \mathrm{O}_{2}\right.$ and $\left.0.8 \% \mathrm{CO}_{2}\right)$ for $21 \mathrm{~d}$ and $0.5 \% \mathrm{O}_{2}$ for $7 \mathrm{~d}$ or (2) $0.5 \% \mathrm{O}_{2}$ for $10 \mathrm{~d}$ followed by controlled atmosphere (CA) $\left(1.5 \% \mathrm{O}_{2}\right.$ and $\left.1 \% \mathrm{CO}_{2}\right)$ for $21 \mathrm{~d}$ and $0.5 \% \mathrm{O}_{2}$ for $7 \mathrm{~d}$. Development of superficial scald was inhibited for up to 10 months and $7 \mathrm{~d}$ shelf life $\left(20^{\circ} \mathrm{C}\right)$ under RLOS + ULO and DCA-CF treatments. Apples stored in RLOS + ULO, RLOS + CA, and DCA-CF had significantly $(p<0.05)$ higher flesh firmness and total soluble solids. The RLOS phases applied with CA or ULO and DCA-CF storage reduced the development of superficial scald by possibly suppressing the oxidation of volatiles implicated in superficial scald development.
\end{abstract}

Keywords: chlorophyll; fluorescence; storage atmosphere; superficial scald

\section{Introduction}

'Granny Smith' apples (Malus $\times$ domestica Borkh.) are susceptible to superficial scald, a serious postharvest physiological disorder adversely affecting fruit quality and marketability [1-3]. Superficial scald is observed as black or brown patches on fruit skin during cold storage and is associated with cell death or necrosis in hypodermal cortical tissue [4]. Although internal quality is usually not affected, development of superficial scald renders fruit unmarketable because of reduced appearance quality [5]. The autooxidation of naturally occurring sesquiterpene $\alpha$-farnesene volatile to conjugated trienols and 6-methyl-5-hepten-2-one (MHO) is probably the main reaction resulting in the manifestation of symptoms of superficial scald $[2,6]$. However, the loss of natural antioxidant metabolites (tocopherol and phenolic compounds) and enzymes, which prevent cell damage by reactive oxygen species, contributes to the development of scald symptoms [5,7]. In addition, low phenolic content in apple peel has been correlated with high superficial scald incidence [8]. Both lipophilic and hydrophilic antioxidants may be involved in superficial scald prevention; however, no specific antioxidant has been consistently linked to $\alpha$-farnesene, $\mathrm{MHO}$, or superficial scald $[4,7,9]$. Additionally, pre-harvest factors such as cultivar, maturity, rootstock, and seasonal differences determine susceptibility to scald development [4]. 
In an attempt to control superficial scald, several methods have been applied to fruit that were either chemical or non-chemical in nature. Of note was diphenylamine, a synthetic antioxidant that successfully inhibited superficial scald until it was banned in Europe because of consumer safety concerns [10]. Low oxygen stress (LOS) storage of apples has been used for many decades as a non-chemical storage technology alternative for apples [3,4]. For instance, initial low oxygen stress (ILOS), anaerobic treatment for 9-14 d, before controlled atmosphere (CA), ultra-low oxygen (ULO), or regular atmosphere (RA) has been reported to effectively prevent the development of superficial scald in 'Granny Smith', Starkimson', 'Delicious', and 'Royal Gala' apples [11-14]. The mechanism of action is not fully understood. However, hypoxic conditions during storage lead to stimulated and rapid ethanol production in the fruit pulp, which presumably limits the oxidation of $\alpha$-farnesene in the peel $[4,15]$. Ethanol vapors have shown inhibitory effects against superficial scald when exposed to various apple cultivars, further supporting this hypothesis $[16,17]$.

In recent years, $\mathrm{CA}$ technologies have gained a lot of attention, particularly dynamic controlled atmosphere (DCA) [3]. The storage technology regularly adjusts gas composition during storage using biosensors, namely chlorophyll fluorescence (DCA-CF), respiration quotient (DCA-RQ), and ethanol (DCA-ET) [2,3]. Research studies by Mditshwa et al. [2] demonstrated the efficacy of repeated application of DCA-CF to control superficial scald $(2 \%)$ on 'Granny Smith' apples when stored for $16 \mathrm{w}$ in DCA-CF with a $14 \mathrm{~d}$ of interruption with regular atmosphere (RA) at $-0.5{ }^{\circ} \mathrm{C}$ and $95 \%$ relative humidity (RH). Similarly, research work has also shown that DCA-CF storage maintains fruit firmness, inhibits the development of decay, and preserves Gala's internal quality [18] and 'Granny Smith' apples [19].

Despite the demonstrated efficacy of DCA-CF, more studies are still relevant to developing cultivar-specific storage protocols and validating existing results. For example, no evidence of a substantial difference between the sensory parameters of 'Greenstar' apples stored in DCA-CF at two oxygen concentration regimes (0.4 and $0.7 \%)\left(1.2 \pm 0.2^{\circ} \mathrm{C}\right)$ was observed after storage for 10 months, which suggests the need for further optimization studies [20]. Additionally, DCA-CF is subject to errors in determining the low oxygen limit of fruit because chlorophyll fluorescence depends on the metabolic activity of fruit [21,22]. For example, Feng et al. [23] reported variations in metabolic activity of fruit depending on canopy position in a tree. For the three apple cultivars 'McIntosh', 'Gala', and 'Mutsu', the sun-exposed side exhibited elevated rates of metabolism (higher soluble sugars, sugar alcohols, ascorbic acid, and succinic acids in the peel) compared to the shaded side.

Recent studies, according to Bessemans et al. [24], showed better fruit quality in 'Granny Smith' apples subjected to DCA-RQ (0.25-0.4 $\left.\mathrm{kPa} \mathrm{O}_{2}\right)$ compared to standard CA storage at low ethanol concentration $\left(<0.028 \mathrm{~g} \mathrm{~L}^{-1}\right)$ in the fruit pulp. The quality of the fruit resembled that of 1-Methylcyclopropene (1-MCP) treated (preceded with CA) apples after $7 \mathrm{~d}$ at $18{ }^{\circ} \mathrm{C}$. In a study on 'Royal Gala' apples, Weber et al. [22] showed that fruit stored in DCA-RQ had superior quality (less flesh breakdown) compared to static CA after 8 months of cold storage $\left({ }^{\circ} \mathrm{C}\right)$. Despite the notable benefits in adopting DCA-RQ, the use of RQ is usually feasible under strict and gas tight conditions, unattainable in most CA rooms due to leakage [25]. In addition, this storage technique is feasible in controlled laboratory conditions with sensitive instruments that can accurately measure oxygen consumption rates and $\mathrm{CO}_{2}$ production $[22,24]$.

Application of DCA-ET, also known as repeated low oxygen stress (RLOS), is based on determination of low oxygen limit (LOL) through either the destructive measurements of ethanol content from fruit pulp (estimated to be $1 \mathrm{ppm}$ ) or headspace analysis with sensors, notably DCS ${ }^{\mathrm{TM}}$ (Storex, Gravendeel) [3]. Few studies have reported the commercial application of DCA-ET beyond the ongoing research work in the Netherlands on different apple cultivars ('Elstar' and 'Jonagold') [21]. The study by Veltman et al. [26] investigated the effects of DCA-ET using Chrompack gas chromatography to regulate ethanol levels in the fruit pulp of 'Elstar' apples during cold storage $\left(1^{\circ} \mathrm{C}\right)$. The results showed that, 
in addition to less skin spot development, the fruit had better color and firmness retention than standard CA $\left(1.2 \% \mathrm{O}_{2}\right.$ and $\left.2.5 \% \mathrm{CO}_{2}\right)$. However, there is limited information available on the application of the RLOS technology in other important apple cultivars such as 'Granny Smith', and the mechanism of action of RLOS is not clearly understood.

This study will further evaluate RLOS phases' effects on the incidence of physiological disorders and internal quality of the 'Granny Smith' apples during long-term storage. The study also assessed changes in radical scavenging activity, total phenolic content, and selected volatiles of 'Granny Smith' apples subjected to DCA-CF and RLOS storage technologies.

\section{Materials and Methods}

\subsection{Fruit Supply, Treatments and Storage}

'Granny Smith' apples were harvested at 172 days after full bloom (DAFB) with an average starch breakdown $=36.3 \%$ and firmness $=79 \mathrm{~N}$ from Grabouw $\left(34^{\circ} 12^{\prime} 12^{\prime \prime} \mathrm{S}\right.$, $19^{\circ} 02^{\prime} 35^{\prime \prime} \mathrm{E}$ ), Western Cape, South Africa. Fruit were transported to the research laboratory at the Agricultural Research Council (ARC), Stellenbosch, South Africa. 'Granny Smith' apples were sorted for external damages, packaged in crates (90-120 fruit per crate), and stored at $0{ }^{\circ} \mathrm{C}$. Each treatment had 3 replications ( 1 crate $=1$ replication $=90-120$ fruit). Subsequently, 'Granny Smith' apples were subjected to the following repeated low oxygen stress (RLOS) treatments: (1) low oxygen stress at $0.5 \% \mathrm{O}_{2}$ for $10 \mathrm{~d}$ followed by ultra-low oxygen (ULO) $\left(0.9 \% \mathrm{O}_{2}\right.$ and $\left.0.8 \% \mathrm{CO}_{2}\right)$ for $21 \mathrm{~d}$ and low oxygen stress at $0.5 \%$ for $7 \mathrm{~d}$, (2) low oxygen stress at $0.5 \% \mathrm{O}_{2}$ for $10 \mathrm{~d}$ followed by controlled atmosphere (CA) $\left(1.5 \% \mathrm{O}_{2}\right.$ and $1 \% \mathrm{CO}_{2}$ ) for $21 \mathrm{~d}$, and low oxygen stress at $0.5 \% \mathrm{O}_{2}$ for $7 \mathrm{~d}$.

Existing CA cold rooms were installed with the HarvestWatch ${ }^{\circledR}$ (SAtlantic Inc., Halifax, NS, Canada) chlorophyll fluorescence non-destructive monitoring system. The interactive response monitor sensor (FIRM) was used to detect the low oxygen limit (LOL) of the fruit and monitor the physiological response of the fruit to low oxygen levels hourly. Following the storage protocol reported by Mditshwa et al. [2], 'Granny Smith' apples were loaded into cold rooms, and a core temperature of $-0.5^{\circ} \mathrm{C}$ was achieved within $48-96 \mathrm{~h}$ after harvest. Low oxygen limit of the fruit was detected within $48 \mathrm{~h}$ after harvest, using compressed air, carbon dioxide, and nitrogen from a membrane generator (Isosep, Isolcell, Italy). The LOL was set at $0.3 \% \mathrm{O}_{2}$ for both harvest seasons (2015 and 2016), after which it was set to $0.6 \% \mathrm{O}_{2}$ for the entire storage period. In this study, gas composition needed to be adjusted to prevent a shift to the anaerobic respiration of fruit, so the storage room chamber was analyzed at $90 \mathrm{~min}$ intervals. Fruit were also stored in RA at $0{ }^{\circ} \mathrm{C}\left(\approx 21 \% \mathrm{O}_{2}\right.$ and $90-95 \%$ RH). The study was repeated over two consecutive seasons (2015 and 2016). In summary, 'Granny Smith' apples were stored using the following treatments (1-4):

1. RLOS + ULO: Cycles of RLOS $\left(0.5 \% \mathrm{O}_{2}\right.$ for $\left.10 \mathrm{~d}\right)$ followed ULO $\left(0.9 \% \mathrm{O}_{2}\right.$ and $0.8 \%$ $\mathrm{CO}_{2}$ for $21 \mathrm{~d}$ and $0.5 \% \mathrm{O}_{2}$ for $7 \mathrm{~d}$ );

2. RLOS + CA: Cycles of RLOS $\left(0.5 \% \mathrm{O}_{2}\right.$ for $\left.10 \mathrm{~d}\right)$ followed by CA $\left(1.5 \% \mathrm{O}_{2}\right.$ and $1 \% \mathrm{CO}_{2}$ for $21 \mathrm{~d}$ and $0.5 \% \mathrm{O}_{2}$ for $7 \mathrm{~d}$ );

3. DCA-CF: Storage at $0.6 \% \mathrm{O}_{2}$ and $0.8 \% \mathrm{CO}_{2}$;

4. RA: Storage at $\approx 21 \% \mathrm{O}_{2}$ and $90-95 \% \mathrm{RH}$.

\subsection{Assessment of Quality and Analysis}

\subsubsection{Physiological Disorders}

Superficial Scald

Fruit with superficial scald were counted and expressed as a percentage of the total number of fruit in a single replication (90-120 fruit) [5]. Observations of the symptoms were done after a $6 \mathrm{w}$ simulated shipping and handling period at $-0.5^{\circ} \mathrm{C}$ and $7 \mathrm{~d}$ shelf life $\left(20{ }^{\circ} \mathrm{C}\right.$ and $\left.65 \% \mathrm{RH}\right)$. 


\section{Coreflush}

A sample of 10 fruit was taken of each replicate (90-120 fruit) from each treatment, each fruit being cut open for a rating of coreflush incidence. Fruit with coreflush were counted and expressed as a percentage of the total number of fruit per sample [27]. This was done after a $6 \mathrm{w}$ simulated shipping and handling period at $-0.5{ }^{\circ} \mathrm{C}$ and $7 \mathrm{~d}$ shelf life $\left(20^{\circ} \mathrm{C}\right.$ and $\left.65 \% \mathrm{RH}\right)$.

\subsubsection{Physicochemical Properties}

Firmness

A Fruit Texture Analyzer (FTA 20, Güss, South Africa) with $11.1 \mathrm{~mm}$ compression probe was used to measure flesh firmness [28]. To measure flesh firmness for each replicate (10 fruit), each fruit was peeled equatorially on opposite sides, the plunger was pressed into the peeled flesh, and the firmness reading recorded. The operating conditions of the instrument were: pre-test speed $1.5 \mathrm{~mm} \mathrm{~s}^{-1}, 0.5 \mathrm{~mm} \mathrm{~s}^{-1}$ test speed, $10.0 \mathrm{~mm} \mathrm{~s}^{-1}$ post-test speed, and $0.20 \mathrm{~N}$ trigger force. The average reading from both sides was used.

\section{Total Soluble Solids and Titratable Acidity}

To measure total soluble solids (TSS), fruit segments ( $\approx 20 \mathrm{~g}$ of each fruit) were cut transversely from 10 randomly selected fruit per replicate. The fruit segments were processed for juice using a domestic juicer (Mellerware Liquafresh juice extractor III). The juice was homogenized by mixing and stabilizing for five minutes, and $5 \mathrm{~mL}$ was sampled using a syringe for TSS measurements. Total soluble solids content was obtained using a calibrated refractometer (Pocket refractometer PAL ${ }^{-1}$, ATAGO Co. LTD, Tokyo, Japan) [29]. Standardization was done using distilled water (refractive index of 0 ). The refractometer was rinsed between readings to maintain accurate measurements of TSS. To measure titratable acidity (TA), $20 \mathrm{~g}$ of fruit segments were cut from each of the 10 fruit (per replicate) and a $46 \mathrm{~mL}$ juice sample was blended and titrated against $0.333 \mathrm{~N}$ of sodium hydroxide $(\mathrm{NaOH})$ to a $\mathrm{pH}$ of 8.2 using a Crison Titromatic 1S/2B (Crison Instruments, Barcelona, Spain). Titratable acidity was expressed as g of malic acid per $100 \mathrm{~g}$ [29].

\section{Background Color}

A Chroma Meter (CR 400/410 Konica Minolta Sensing Inc., Japan) was used to obtain background color according to the Commission Internationale De I'Eclairage (CIELAB)(L*, $\mathrm{a}^{*}$ and $\mathrm{b}^{*}$ ) system from two opposite positions along the equatorial region of the fruit [30]. The color coordinate $\mathrm{L}^{*}=0$ to 100 (describing black to white), $\mathrm{a}^{*}=$ red $(+) /$ green $(-)$, and $\mathrm{b}^{*}=$ yellow $(+) /$ blue $(-)$. Hue angle $\left(\mathrm{h}^{\circ}\right)$ was used to measure background color and determined according to the following Equation (1):

$$
\mathrm{h}^{\circ}=\arctan \left(\mathrm{b}^{*} / \mathrm{a}^{*}\right)
$$

where $a^{*}$ represents redness and greenness and $b^{*}$ represents yellowness and blueness.

\subsubsection{Headspace Volatile Analysis}

Fruit were sampled at harvest, after each storage period, and after a $6 \mathrm{w}$ simulated shipping and handling period followed by $7 \mathrm{~d}$ shelf life. Apple peel was carefully obtained from four regions of each fruit using a stainless steel peeler (Sigma-Aldrich, Johannesburg, South Africa). A sample of 10 fruit was obtained from each replicate, peeled, cut into smaller pieces, and $5 \mathrm{~g}$ was weighed into $20 \mathrm{~mL}$ solid phase microextraction (SMPE) glass vials. Ten microlitres of 3-octanol or anisole/methyoxybenzene solution were added as an internal standard to the vials, after which they were sealed. Three replicates were prepared for each treatment $(1$ glass vials $=1$ replicate $=5 \mathrm{~g}$ apple peel). The solid phase microextraction (SPME) method was used for headspace volatile analysis [9,31]. Equilibration of vials was done for $10 \mathrm{~min}$ in an autosampler incubator (CTC Analytics AG, Zwingen, Switzerland) set at $50{ }^{\circ} \mathrm{C}$. Volatile compounds in the headspace were trapped on a 50/30 $\mu \mathrm{m}$ divinylbenzene- 
carboxen-polydimethylsiloxane coated fiber after exposure for $20 \mathrm{~min}$ at $50{ }^{\circ} \mathrm{C}$. Volatile compounds on the fiber coating were then desorbed for $2 \mathrm{~min}$ in the injection port of the gas chromatograph, operated in splitless mode at a temperature of $250{ }^{\circ} \mathrm{C}$. Preconditioning of the fiber was done for $2 \mathrm{~min}$ at a temperature of $50^{\circ} \mathrm{C}$ and $250 \mathrm{rpm}$ followed by volatile compound chromatographic separation using a polar capillary column $(60 \mathrm{~m} 0.25 \mathrm{~mm}$ i.d., $0.5 \mu \mathrm{m}$ film thickness) (Agilent Technologies DB-FFAP, model J \& W 122-3263). The oven was set at a temperature of $40^{\circ} \mathrm{C}$, held for $5 \mathrm{~min}$, and then rapidly increased to $230^{\circ} \mathrm{C}$ for $6 \mathrm{~min}$. The total run time for the method was $30 \mathrm{~min}$. Helium was used as a carrier gas at a constant flow rate of $1 \mathrm{~mL} / \mathrm{min}$. The ion source and quadropole were kept at $240{ }^{\circ} \mathrm{C}$ and $150{ }^{\circ} \mathrm{C}$, respectively. The transfer line temperature was kept at $280^{\circ} \mathrm{C}$.

\subsubsection{Biochemical Analysis \\ Total Phenolic Content}

Measurement of total phenolic content of apple peel was done using the FolinCiocalteu method according to Mditshwa et al. [9], with slight modifications. In triplicates, $50 \mu \mathrm{L}$ of 4 -fold diluted crude extract was added to $450 \mu \mathrm{L}$ of $50 \%$ methanol, followed by $500 \mu \mathrm{L}$ Folin-C reagent and then sodium carbonate ( $2 \%)$ solution after $2 \mathrm{~min}$. The mixture was vortexed incubated for $40 \mathrm{~min}$ in the dark at room temperature, and absorbance was measured at $725 \mathrm{~nm}$ using a UV-visible spectrophotometer (Thermo Scientific Technologies, Madison, Wisconsin). Total phenolic content in the extract was extrapolated using a gallic acid calibration curve. Results were expressed as mean (milligrams) of gallic acid equivalents per unit dry matter (mg GAE/g DM) of peel in triplicate samples.

\section{Radical Scavenging Activity}

Radical scavenging activity (RSA) from apple peel extract was determined according to Mditshwa et al. [9]. In triplicates, $15 \mu \mathrm{L}$ of 3-fold diluted crude extract was added to $735 \mu \mathrm{L}$ of $50 \%$ methanol followed by $750 \mu \mathrm{L}$ 2,2-diphenyl-1-picrylhydrazyl (DPPH) $(0.1 \mathrm{mM})$ solution. The mixture was incubated for $30 \mathrm{~min}$ in the dark at room temperature before measuring the absorbance at $517 \mathrm{~nm}$ using a UV-visible spectrophotometer (Thermo Scientific Technologies, Madison, WI, USA). Ascorbic acid concentration was used to generate a calibration curve, and RSA in the extract was extrapolated from the calibration curve. The RSA was expressed as the mean (millimolar) of ascorbic acid equivalent per milligram of dry matter (mM AAE/mg DM).

\subsubsection{Statistical Analysis}

The experimental design was a completely randomized design with three factors (storage treatment, storage duration, and shelf life). Analysis of variance (ANOVA) was done using SAS software (SAS Enterprise Guide 7.1) and means were separated by least significant difference (LSD; $p=0.05$ ), according to Bonferroni (Dunn) $t$-test. Relationship among the measured parameters was determined by subjecting data to the Pearson correlation test in XLSTAT software version 2012.04.1 (Addinsoft, Paris, France). GraphPad Prism software version 8.4.3 (GraphPad Software, Inc., San Diego, CA, USA) was used for graphical presentations.

\section{Results}

3.1. Physiological Disorders

3.1.1. Superficial Scald

In the 2015 season (Table 1$)$, superficial scald incidence was significantly $(p=0.0003)$ influenced by three-way interaction amongst the main effects (storage treatments, storage duration, and shelf life). The treatment contribution to the three-way interaction could be attributed to significantly higher superficial scald development on RA stored 'Granny Smith' apples than RLOS (ULO and CA) and DCA-CF stored fruit. No incidence of superficial scald was observed on fruit subjected to RLOS + ULO and DCA-CF treatments at every sampling interval. In the 2016 seasons, superficial scald developed on RLOS (ULO and CA) 
and DCA-CF stored fruit from 6 months until the end of storage. There was no significant difference in superficial scald in the 2015 season for RLOS + ULO and RLOS + CA, whereas in 2016, there was a significant difference at 6 months and 7 days shelf life (RLOS + ULO $=32.38 \%$, RLOS $+\mathrm{CA}=0 \%$, and DCA-CF $=3.36 \%$ ). Overall, the results showed minimal risk of superficial scald development for DCA-CF stored 'Granny Smith' apples over the two seasons.

Table 1. Superficial scald incidence (\%) on 'Granny Smith' apples harvested at commercial maturity (with no superficial scald at harvest) and stored for up to 10 months at $0{ }^{\circ} \mathrm{C}$ in various storage conditions, evaluated every two months followed by a 6 week simulated shipment and handling period, and at 7 days on the shelf $\left(20^{\circ} \mathrm{C}\right.$ and $\left.65 \% \mathrm{RH}\right)$.

\begin{tabular}{|c|c|c|c|c|c|c|}
\hline \multirow{2}{*}{ Season } & \multirow{2}{*}{$\begin{array}{l}\text { Storage Duration } \\
\text { (Months) }\end{array}$} & \multirow{2}{*}{ Shelf-Life (Days) } & \multicolumn{4}{|c|}{ Superficial Scald $(\%)$} \\
\hline & & & RLOS + ULO & RLOS + CA & DCA-CF & RA \\
\hline \multirow[t]{10}{*}{2015} & 2 & 0 & $0.00 \pm 0.00^{\mathrm{d}}$ & $0.00 \pm 0.00^{\mathrm{d}}$ & $0.00 \pm 0.00^{d}$ & $0.00 \pm 0.00^{d}$ \\
\hline & & 7 & $0.00 \pm 0.00^{d}$ & $0.00 \pm 0.00^{\mathrm{d}}$ & $0.00 \pm 0.00^{d}$ & $0.00 \pm 0.00^{d}$ \\
\hline & 4 & 0 & $0.00 \pm 0.00^{\mathrm{d}}$ & $0.00 \pm 0.00^{\mathrm{d}}$ & $0.00 \pm 0.00^{d}$ & $90.86 \pm 8.45^{b}$ \\
\hline & & 7 & $0.00 \pm 0.00^{\mathrm{d}}$ & $0.00 \pm 0.00^{\mathrm{d}}$ & $0.00 \pm 0.00^{\mathrm{d}}$ & $100.00 \pm 0.00^{\mathrm{a}}$ \\
\hline & 6 & 0 & $0.00 \pm 0.00^{d}$ & $0.00 \pm 0.00^{\mathrm{d}}$ & $0.00 \pm 0.00^{d}$ & $100.00 \pm 0.00^{\mathrm{a}}$ \\
\hline & & 7 & $0.00 \pm 0.00^{\mathrm{d}}$ & $0.00 \pm 0.00^{d}$ & $0.00 \pm 0.00^{d}$ & $100.00 \pm 0.00^{\mathrm{a}}$ \\
\hline & 8 & 0 & $0.00 \pm 0.00^{\mathrm{d}}$ & $0.00 \pm 0.00^{\mathrm{d}}$ & $0.00 \pm 0.00^{\mathrm{d}}$ & $100.00 \pm 0.00^{\mathrm{a}}$ \\
\hline & & 7 & $0.00 \pm 0.00^{\mathrm{d}}$ & $0.00 \pm 0.00^{\mathrm{d}}$ & $0.00 \pm 0.00^{\mathrm{d}}$ & $100.00 \pm 0.00^{\mathrm{a}}$ \\
\hline & 10 & 0 & $0.00 \pm 0.00^{d}$ & $0.00 \pm 0.00^{d}$ & $0.00 \pm 0.00^{d}$ & $100.00 \pm 0.00^{\mathrm{a}}$ \\
\hline & & 7 & $0.00 \pm 0.00^{\mathrm{d}}$ & $7.06 \pm 7.96^{\mathrm{d}}$ & $0.00 \pm 0.00^{\mathrm{d}}$ & $100.00 \pm 0.00^{\mathrm{a}}$ \\
\hline \multirow[t]{19}{*}{2016} & 2 & 0 & $0.00 \pm 0.00^{\mathrm{c}}$ & $0.00 \pm 0.00^{\mathrm{c}}$ & $0.00 \pm 0.00^{c}$ & $0.00 \pm 0.00^{\mathrm{c}}$ \\
\hline & & 7 & $0.00 \pm 0.00^{c}$ & $0.00 \pm 0.00^{c}$ & $0.00 \pm 0.00^{c}$ & $84.92 \pm 6.80^{\mathrm{a}}$ \\
\hline & 4 & 0 & $0.00 \pm 0.00^{c}$ & $0.00 \pm 0.00^{c}$ & $0.00 \pm 0.00^{c}$ & $29.24 \pm 10.63^{b}$ \\
\hline & & 7 & $0.00 \pm 0.00^{c}$ & $0.00 \pm 0.00^{c}$ & $0.00 \pm 0.00^{c}$ & $100.00 \pm 0.00^{a}$ \\
\hline & 6 & 0 & $0.00 \pm 0.00^{\mathrm{c}}$ & $0.00 \pm 0.00^{c}$ & $0.00 \pm 0.00^{c}$ & $97.48 \pm 2.22^{\mathrm{a}}$ \\
\hline & & 7 & $32.38 \pm 24.12^{b}$ & $0.00 \pm 0.00^{c}$ & $3.36 \pm 1.07^{\mathrm{c}}$ & $100.00 \pm 0.00^{\mathrm{a}}$ \\
\hline & 8 & 0 & $0.00 \pm 0.00^{\mathrm{c}}$ & $0.00 \pm 0.00^{c}$ & $0.00 \pm 0.00^{c}$ & $100.00 \pm 0.00^{a}$ \\
\hline & & 7 & $0.00 \pm 0.00^{c}$ & $5.17 \pm 5.45^{c}$ & $1.31 \pm 2.26^{c}$ & $100.00 \pm 0.00^{\mathrm{a}}$ \\
\hline & 10 & 0 & $2.78 \pm 2.64^{\mathrm{c}}$ & $4.88 \pm 2.32^{c}$ & $0.00 \pm 0.00^{c}$ & $100.00 \pm 0.00^{\mathrm{a}}$ \\
\hline & & 7 & $32.04 \pm 13.60^{b}$ & $32.15 \pm 7.79^{b}$ & $2.41 \pm 1.63^{\mathrm{def}}$ & $100.00 \pm 0.00^{\mathrm{a}}$ \\
\hline & \multicolumn{6}{|c|}{$\operatorname{Pr}>F$} \\
\hline & Season & 2015 & & 2016 & & \\
\hline & Treatment (A) & $<0.0001$ & & $<0.0001$ & & \\
\hline & Storage duration (B) & $<0.0001$ & & $<0.0001$ & & \\
\hline & Shelf life (C) & 0.0186 & & $<0.0001$ & & \\
\hline & $\mathrm{A} \times \mathrm{B}$ & $<0.0001$ & & $<0.0001$ & & \\
\hline & $\mathrm{A} \times \mathrm{C}$ & 0.0729 & & $<0.0001$ & & \\
\hline & $\mathrm{B} \times \mathrm{C}$ & 0.0729 & & $<0.0001$ & & \\
\hline & $\mathrm{A} \times \mathrm{B} \times \mathrm{C}$ & 0.0003 & & $<0.0001$ & & \\
\hline
\end{tabular}

Mean \pm standard deviation in the same column followed by different letter(s) are significantly different $(p<0.05)$ according to least significant difference (LSD) $t$-test. RLOS—repeated low oxygen stress; ULO-ultra-low oxygen; CA—controlled atmosphere; DCA-CFdynamic controlled atmosphere-chlorophyll fluorescence; RA-regular atmosphere.

\subsubsection{Coreflush}

In the 2015 season (Table 2), there was an onset of coreflush after 6 months for apples stored in RLOS (ULO $=77 \%$ and CA $=87 \%)$ and DCA-CF $(80 \%)$. However, fruit subjected to RA storage had an onset of coreflush incidence $(100 \%)$ after 8 months. This observation suggests that the maximum storage duration before the risk of coreflush development for 'Granny Smith' apples was 6 months. Contrary to the first season, in the 2016 season, coreflush developed at certain storage intervals without forming a trend. Fruit subjected to RLOS + ULO phases developed coreflush after 2, 6, and 10 months of storage. Moreover, fruit subjected to RLOS + CA treatment recorded $100 \%$ coreflush after 2 months of storage. Overall, the results highlighted the inefficacy of low oxygen technologies to prevent coreflush incidence over the entire 10 months of storage and shelf life. 
Table 2. Coreflush incidence (\%) on 'Granny Smith' apples harvested at commercial maturity (with no coreflush incidence at harvest) and stored for up to 10 months at $0{ }^{\circ} \mathrm{C}$ in various storage conditions, evaluated every two months followed by a 6 week simulated shipment and handling period, and at 7 days on the shelf $\left(20^{\circ} \mathrm{C}\right.$ and $\left.65 \% \mathrm{RH}\right)$.

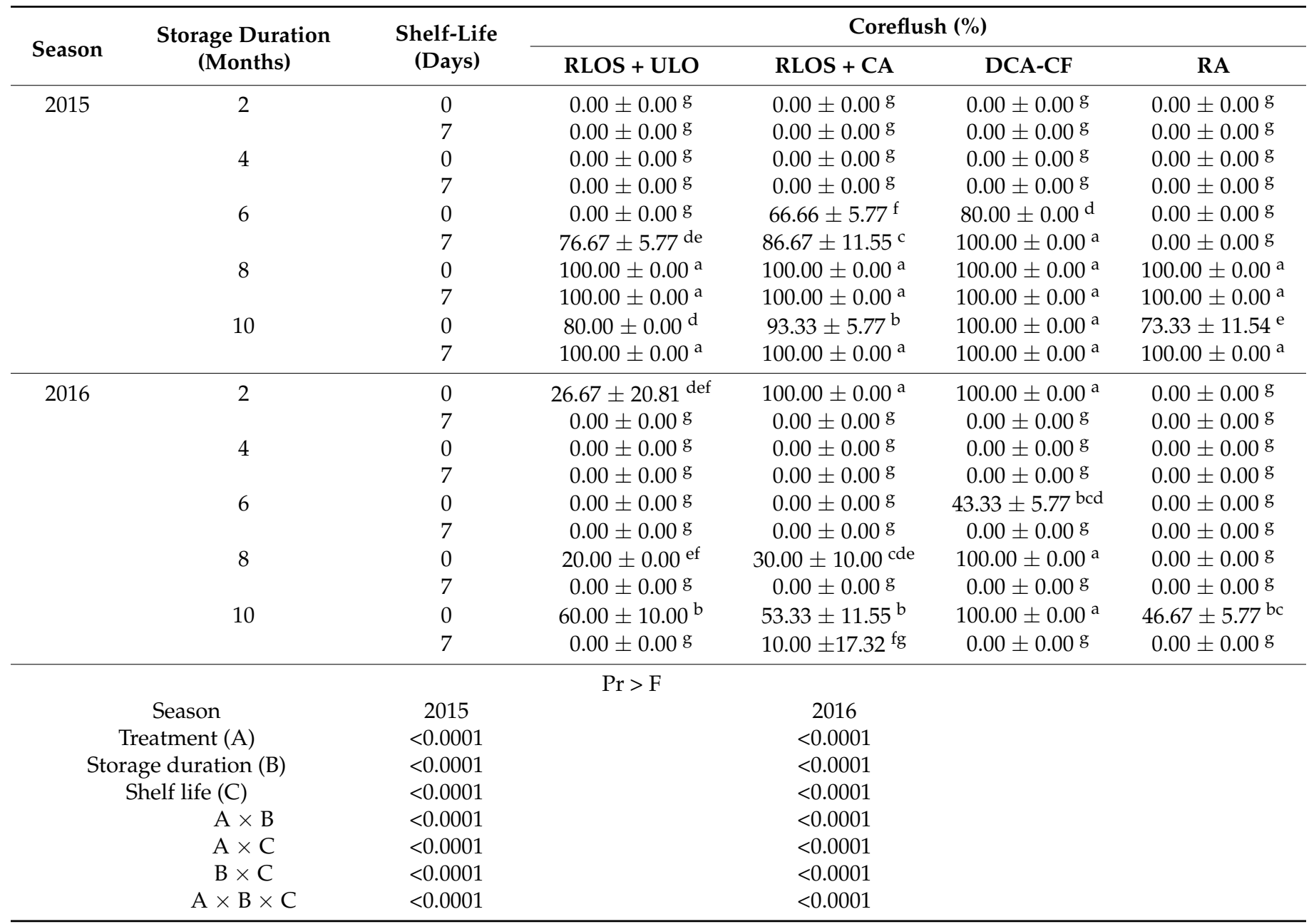

Mean \pm standard deviation in the same column followed by different letter(s) are significantly different $(p<0.05)$ according to least significant difference (LSD) $t$-test. RLOS—repeated low oxygen stress; ULO—ultra-low oxygen; CA—controlled atmosphere; DCA-CFdynamic controlled atmosphere-chlorophyll fluorescence; RA—regular atmosphere.

\subsection{Physicochemical Properties}

\subsubsection{Flesh Firmness}

In the 2015 season, compared to RLOS and DCA-CF treatments, lower flesh firmness was observed in RA treated apples between 6 and 10 months of storage (Figure 1a). However, at 0 and $7 \mathrm{~d}$ shelf life, there was no significant difference in flesh firmness for fruit stored in RLOS (ULO and CA) and DCA-CF treatments. Similarly, in the 2016 season, better firmness retention was associated with fruit stored in low oxygen storage technologies (DCA-CF and RLOS) (Figure 1b) compared to RA. 


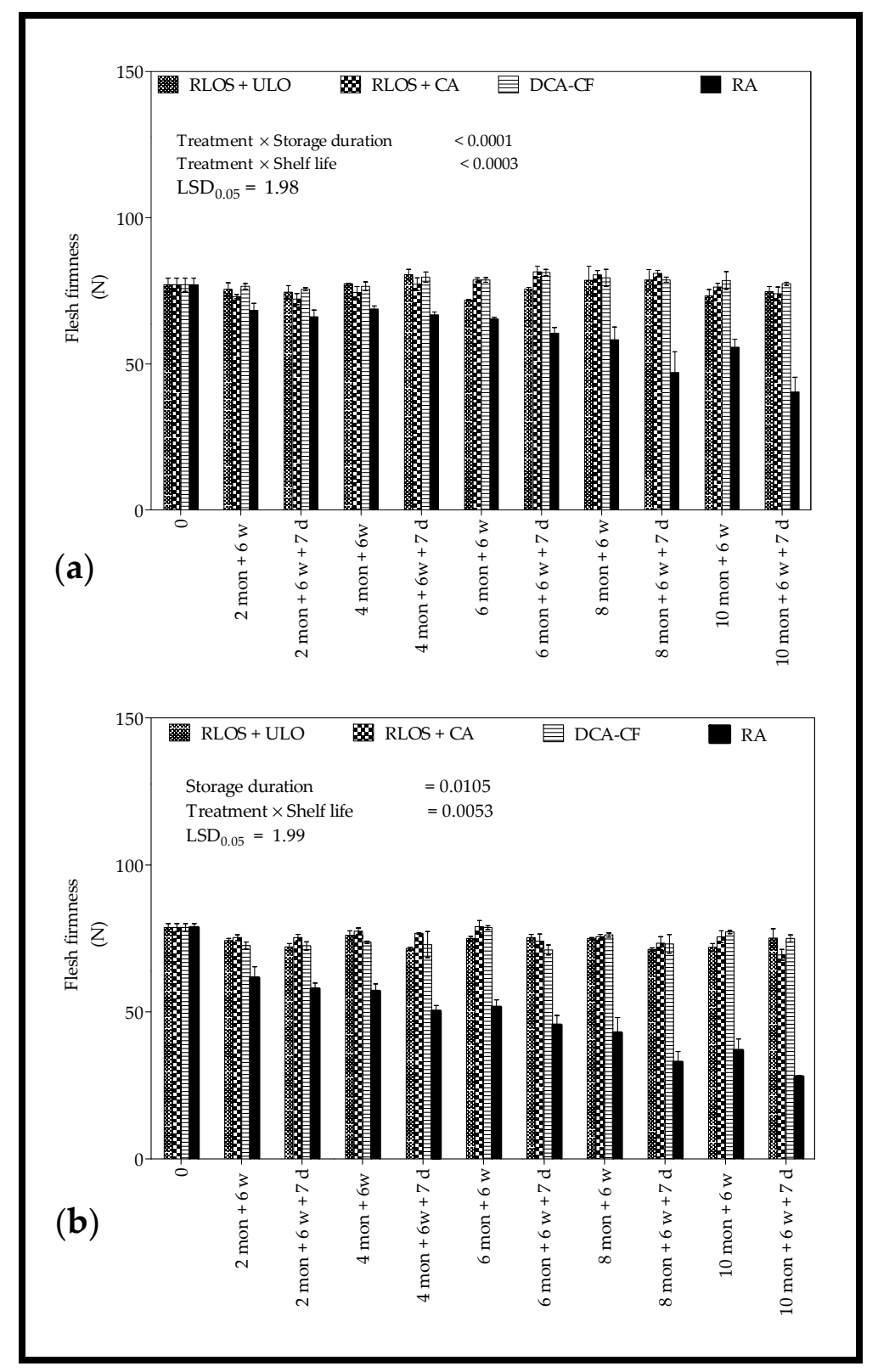

Figure 1. Firmness (N) of 'Granny Smith' apples harvested in the 2015 (a) and 2016 (b) seasons at commercial maturity and stored for up to 10 months at $0{ }^{\circ} \mathrm{C}$ in various storage conditions, evaluated every two months followed by a 6 week simulated shipment and handling period, and at 7 days on the shelf $\left(20^{\circ} \mathrm{C}\right.$ and $\left.65 \% \mathrm{RH}\right)$. Vertical bars represent the standard error (SE) of mean values of 3 replicates ( 1 replicate $=10$ fruit). $\mathrm{LSD}_{0.05}$ represent least significant difference $(p<0.05)$. For storage duration, mon-months, w-weeks, and d-days. RLOS—repeated low oxygen stress; ULO—ultralow oxygen; $\mathrm{CA}$ - controlled atmosphere; DCA-CF—dynamic controlled atmosphere-chlorophyll fluorescence; RA-regular atmosphere.

\subsubsection{Background Color}

In the 2015 season, $L^{*}$ values fluctuated across all treatments, from day 0 to 10 months of storage. The pattern of change for $\mathrm{L}^{*}$ was not clear. However, between 2 and 8 months, $\mathrm{L}^{*}$ values were mostly higher than values at day 0 (Figure $2 \mathrm{a}$ ). In the period between 2 and 10 months, apples stored using RA recorded lesser negative $a^{*}$ values (less green) compared with RLOS (ULO and CA) and DCA-CF treatments (Figure 2b).

As observed in Figure 2c between 2 and 4 months, apples stored using DCA-CF recorded higher $\mathrm{b}^{*}$ values (more yellow) than RLOS (ULO and CA) and RA treatments. 
However, from 4 to 10 months, the pattern of change of $b^{*}$ fluctuated, with apples stored using RA recording the lowest $b^{*}$ values $(6,8$, and 10 months). There was a marked decrease in $h^{\circ}$ of 'Granny Smith' apples from 6 to 10 months of storage in RA (Figure 2d). However, RLOS (ULO and CA) and DCA-CF maintained $\mathrm{h}^{\circ}$ and influence background color retention at 0 and $7 \mathrm{~d}$ shelf life.

In the 2016 season, the pattern of change in $L^{*}$ was not clear (Figure 3a). However, across all storage treatments, $L^{*}$ values recorded at day 0 were lower than other storage periods. The $L^{*}$ values fluctuated, and at certain points $(2,4$, and 8 months), apples stored using RLOS + ULO recorded the highest $L^{*}$ values compared with RLOS + CA, DCA-CF, and RA. Similar to the 2015 season, apples stored using RA mostly recorded less negative $a^{*}$ values (less green) compared with RLOS (ULO and CA) and DCA-CF (Figure 3b). The values for color attribute $b^{*}$ mostly fluctuated during storage, and the differences between storage treatments were mostly not significant (Figure 3c). A similar trend was observed with smaller differences in $\mathrm{h}^{\circ}$ between low oxygen technologies (RLOS + ULO, RLOS + CA, and DCA-CF) and RA storage (Figure 3d). Overall, RLOS (ULO and CA) and DCA-CF appeared to reduce loss of $h^{\circ}$, especially in the 2015 season.

\subsubsection{Total Soluble Solids and Titratable Acidity}

In the first harvest season (2015), the results showed no statistical differences in TSS content between RLOS (ULO and CA) and DCA-CF treated apples (Figure 4a). Across all treatments, TSS content fluctuated during storage. However, in the second harvest season (2016) (Figure $4 \mathrm{~b}$ ), the results showed that low oxygen treatments retained significantly higher TSS content than RA treated fruit. Nevertheless, based on the two seasons, RLOS (ULO and CA) and DCA-CF treatments maintained TSS content significantly higher with RA during long term storage.

In the 2015 harvest season, TA measured from RLOS + CA stored apples decreased from 4 to 10 months storage (Figure 5a). There was a general decrease in TA content during storage of RA treated fruit, with significant changes occurring between 4 to 10 months. The TA content was lower in RA treated fruit than in DCA-CF and RLOS (ULO and CA) treatments, especially from 6 to 10 months. Moreover, there was a decrease in TA from 0 to $7 \mathrm{~d}$ shelf life for RLOS + ULO, RA, and DCA-CF treated fruit. As with the 2015 harvest season, RA treated fruit generally had lower TA content than fruit subjected to RLOS (ULO and $C A$ ) and DCA-CF treatments throughout storage (Figure $5 b$ ). The rate of decrease in TA was higher for RA stored apples compared RLOS (ULO and CA) and DCA-CF treated apples. 

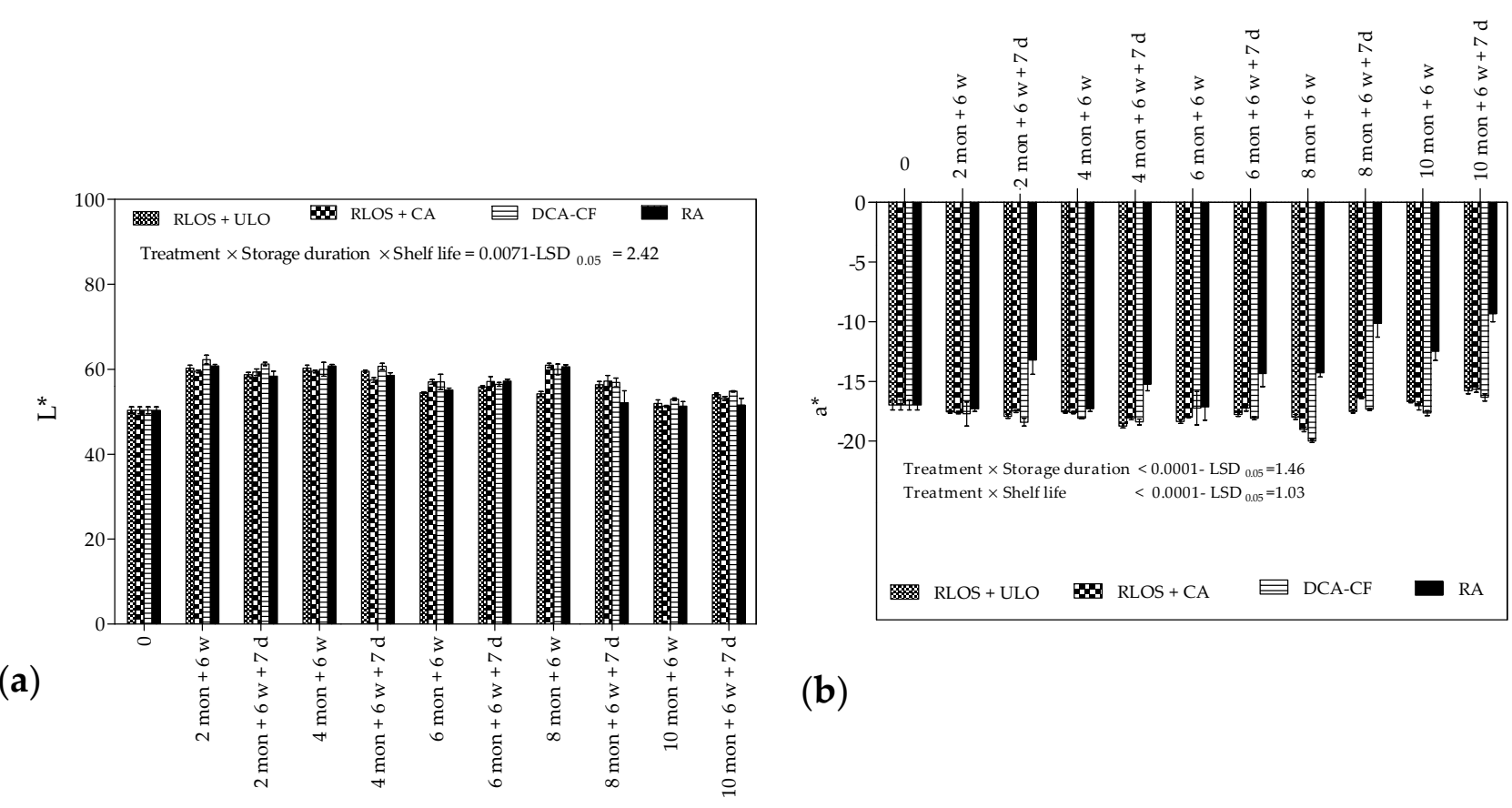

(b)
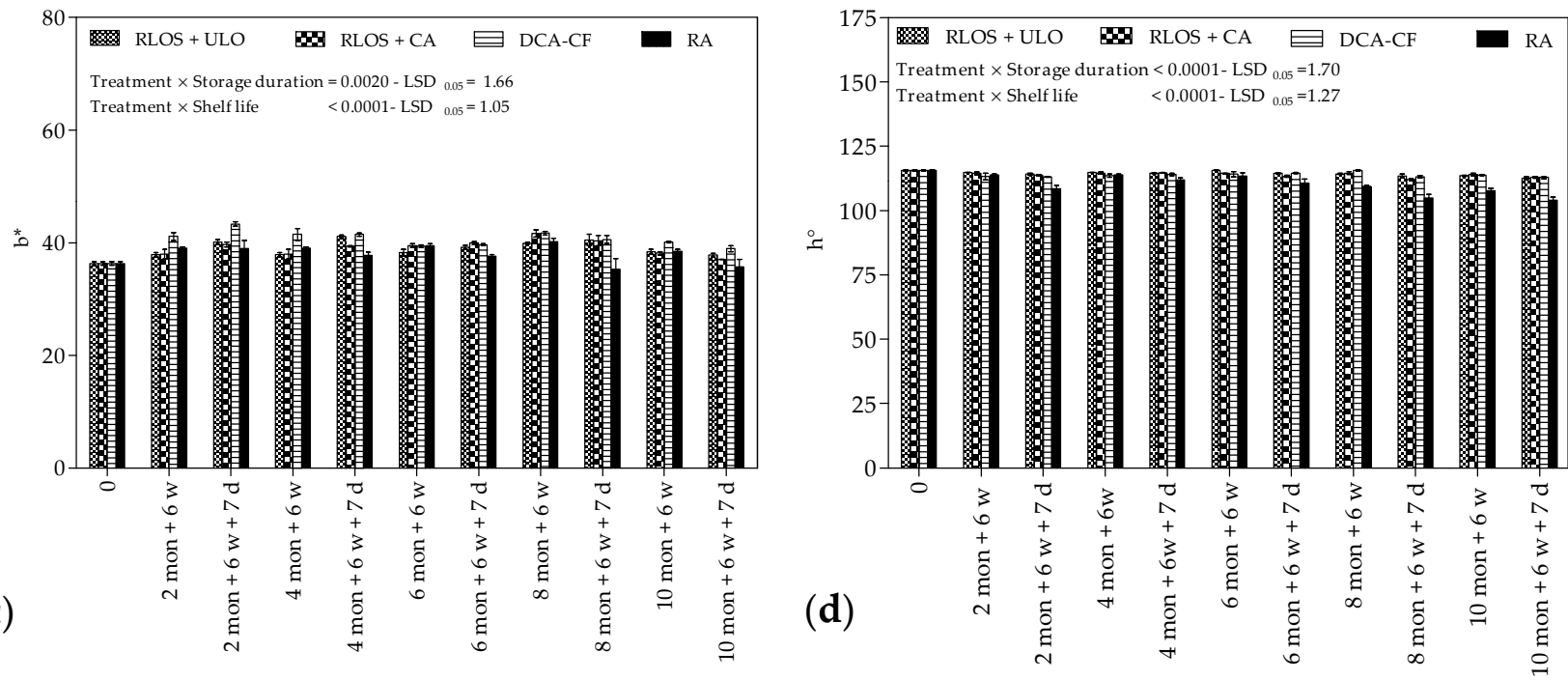

Figure 2. Background color (a) lightness $\left(\mathrm{L}^{*}\right),(\mathbf{b})$ redness/greenness $\left(\mathrm{a}^{*}\right)$, (c) yellowness/blueness $\left(\mathrm{b}^{*}\right)$ and $(\mathbf{d})$ hue angle $\left(\mathrm{h}^{\circ}\right)$ of 'Granny Smith' apples harvested in the 2015 season at commercial maturity and stored for up to 10 months at $0{ }^{\circ} \mathrm{C}$ in various storage conditions, evaluated every two months followed by a 6 week simulated shipment and handling period, and at 7 days on the shelf $\left(20^{\circ} \mathrm{C}\right.$ and $\left.65 \% \mathrm{RH}\right)$. Vertical bars represent the standard error (SE) of mean values of 3 replicates $\left(1\right.$ replicate $=10$ fruit). $\operatorname{LSD}_{0.05}$ represents least significant difference $(p<0.05)$. For storage duration, mon-months; w-weeks; and d-days. RLOS—repeated low oxygen stress; ULO—ultra-low oxygen; CA—controlled atmosphere; DCA-CF—dynamic controlled atmosphere-chlorophyll fluorescence; RA—regular atmosphere. 

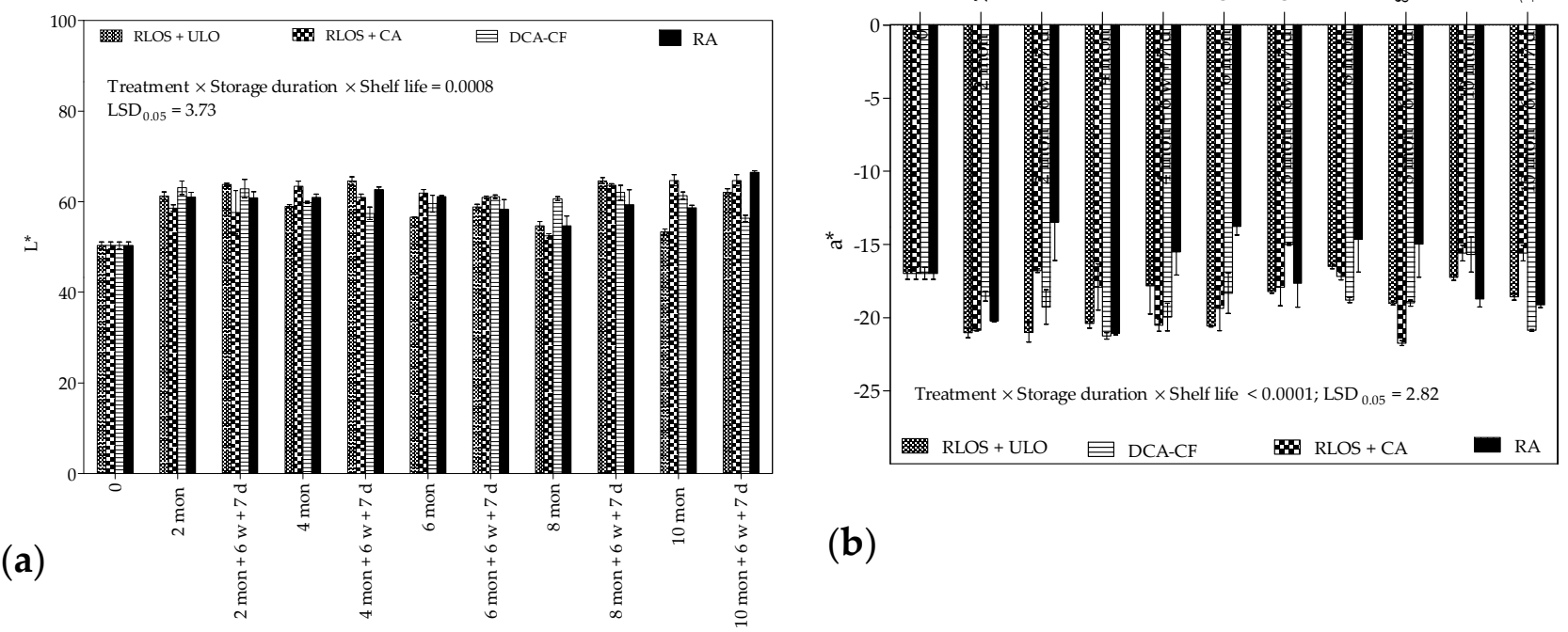

(b)
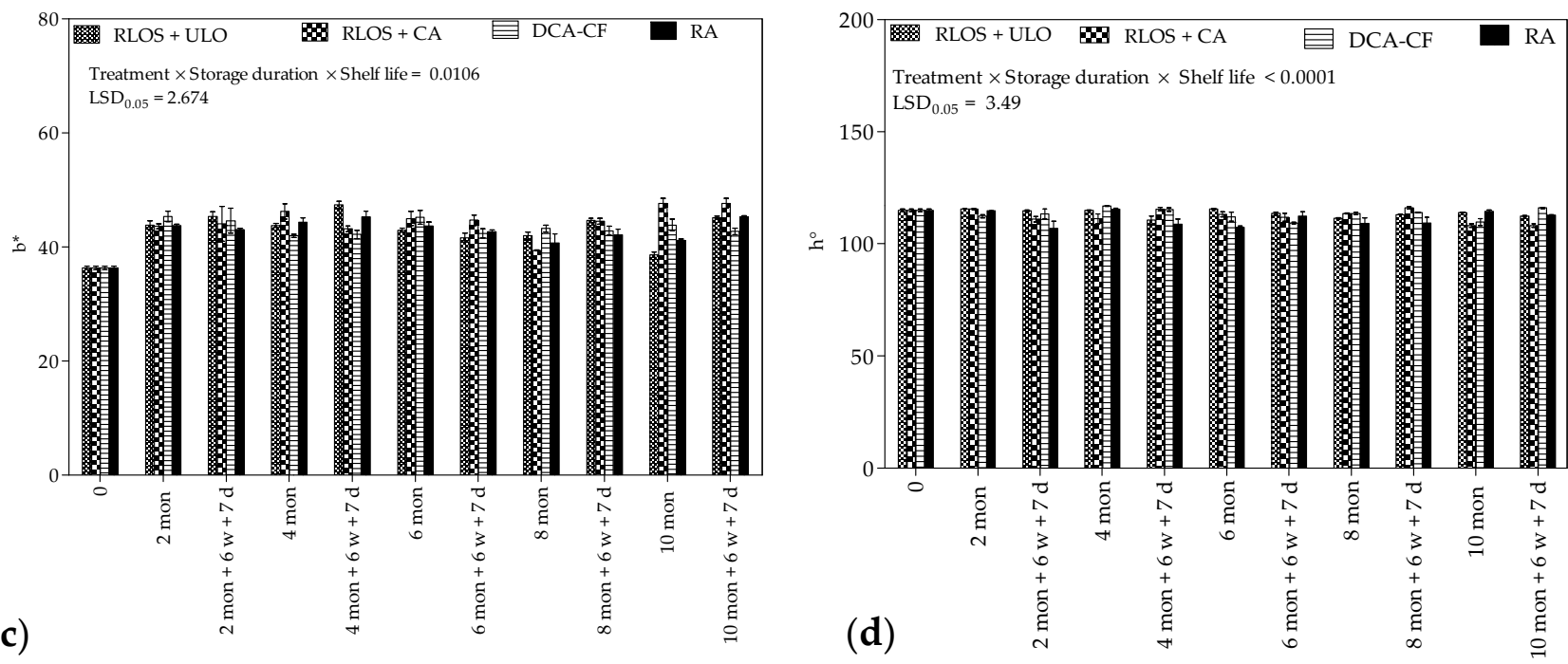

Figure 3. Background color (a) lightness $\left(\mathrm{L}^{*}\right),(\mathbf{b})$ redness/greenness $\left(\mathrm{a}^{*}\right)$, (c) yellowness/blueness $\left(\mathrm{b}^{*}\right)$ and $(\mathbf{d})$ hue angle $\left(h^{\circ}\right)$ of 'Granny Smith' apples harvested in the 2016 season at commercial maturity and stored for up to 10 months at $0{ }^{\circ} \mathrm{C}$ in various storage conditions, evaluated every two months followed by a 6 week simulated shipment and handling period, and at 7 days on the shelf $\left(20^{\circ} \mathrm{C}\right.$ and $\left.65 \% \mathrm{RH}\right)$. Vertical bars represent the standard error (SE) of mean values of 3 replicates $\left(1\right.$ replicate $=10$ fruit). LSD $_{0.05}$ represents least significant difference $(p<0.05)$. For storage duration, mon-months; w-weeks; and d-days. RLOS—repeated low oxygen stress; ULO—ultra-low oxygen; CA—controlled atmosphere; DCA-CF-dynamic controlled atmosphere-chlorophyll fluorescence; RA—regular atmosphere. 


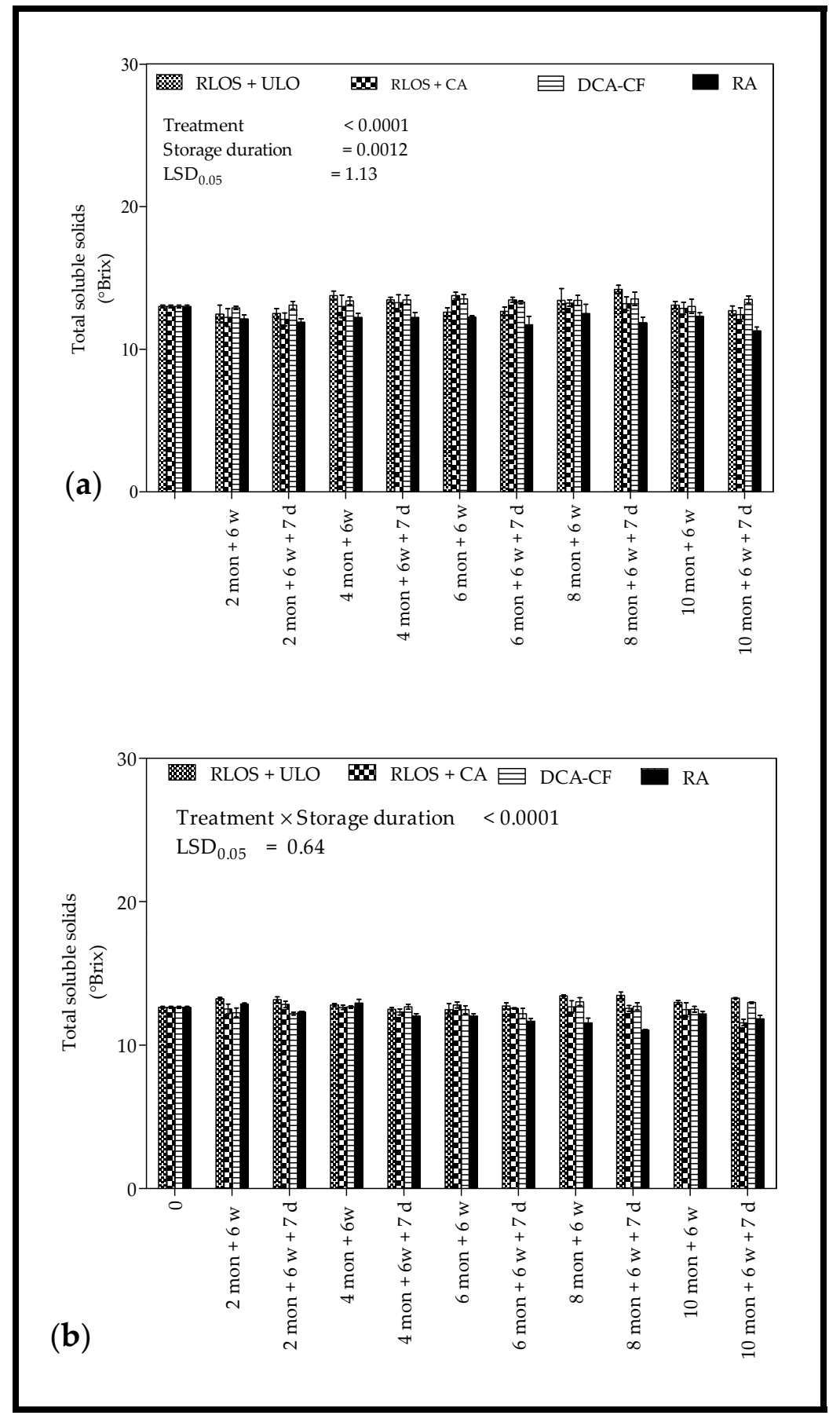

Figure 4. Total soluble solids ( ${ }^{\circ}$ Brix) of 'Granny Smith' apples harvested in the 2015 (a) and 2016 (b) seasons at commercial maturity and stored for up to 10 months at $0{ }^{\circ} \mathrm{C}$ in various storage conditions, evaluated every two months followed by a 6 week simulated shipment and handling period, and at 7 days on the shelf $\left(20^{\circ} \mathrm{C}\right.$ and $\left.65 \% \mathrm{RH}\right)$. Vertical bars represent the standard error (SE) of mean values of 3 replicates ( 1 replicate $=10$ fruit). $\mathrm{LSD}_{0.05}$ represents least significant difference $(p<0.05)$. For storage duration, mon-months; $w$-weeks; and $d$-days. RLOS-repeated low oxygen stress; ULO—ultra-low oxygen; CA—controlled atmosphere; DCA-CF-dynamic controlled atmosphere-chlorophyll fluorescence; RA—regular atmosphere. 


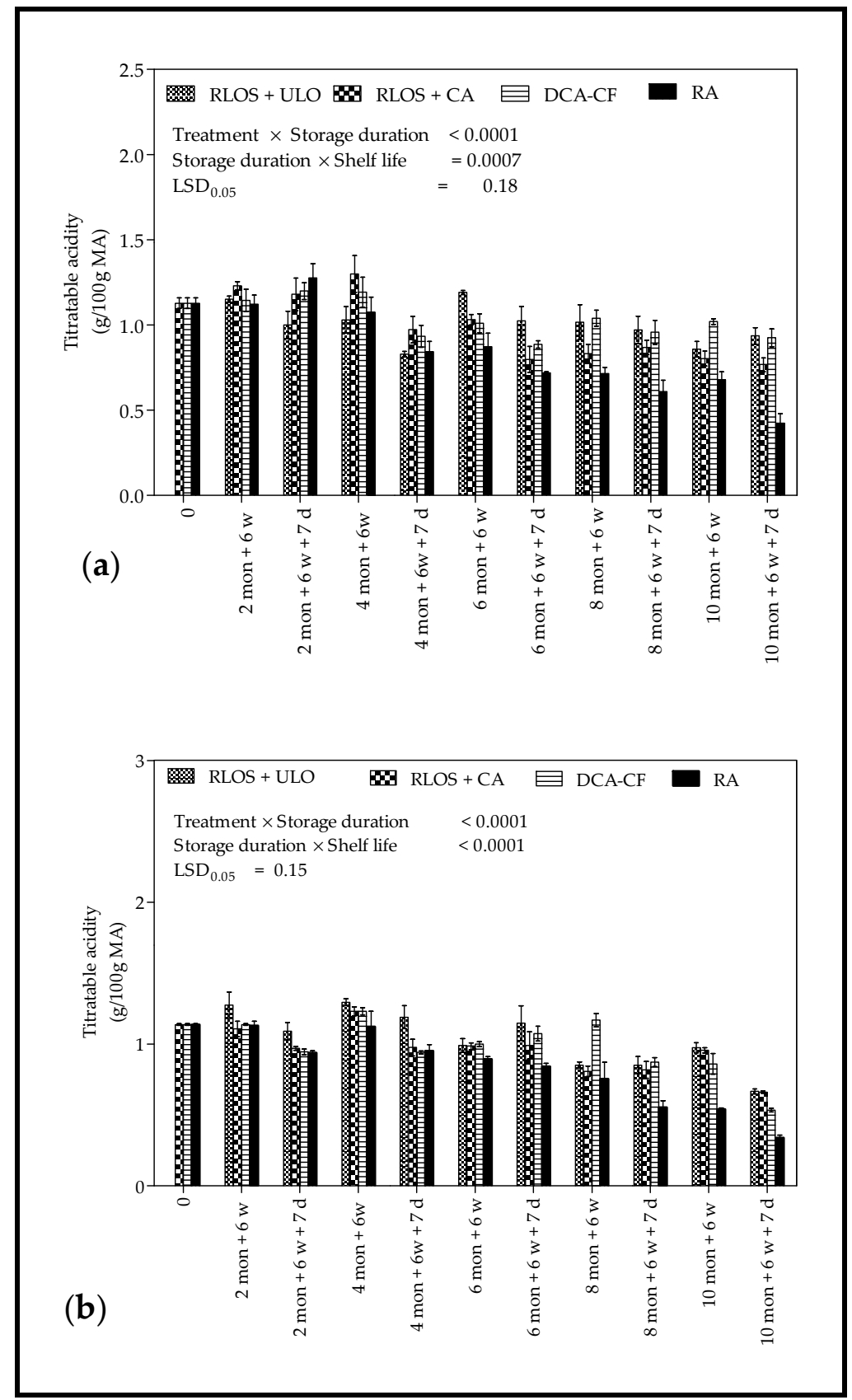

Figure 5. Titratable acidity (g/100 g MA) of 'Granny Smith' apples harvested in the 2015 (a) and 2016 (b) seasons at commercial maturity and stored for up to 10 months at $0{ }^{\circ} \mathrm{C}$ in various storage conditions, evaluated every two months followed by a 6 week simulated shipment and handling period, and at 7 days on the shelf $\left(20^{\circ} \mathrm{C}\right.$ and $\left.65 \% \mathrm{RH}\right)$. Vertical bars represent the standard error (SE) of mean values of 3 replicates ( 1 replicate $=10$ fruit). $\mathrm{LSD}_{0.05}$ represents least significant difference $(p<0.05)$. For storage duration, mon-months; $w$-weeks; and d-days. RLOS-repeated low oxygen stress; ULO — ultra-low oxygen; CA—controlled atmosphere; DCA-CF-dynamic controlled atmosphere-chlorophyll fluorescence; RA—regular atmosphere.

\subsection{Headspace Volatile Analysis}

Changes in $\mathrm{MHO}$ and $\alpha$-farnesene contents during storage for both harvest seasons (2015 and 2016) are presented in Figures 6 and 7, respectively. In the first season (2015), MHO accumulation was markedly higher in RA treated peels from 4 to 6 months $(7 \mathrm{~d}$ shelf life) and from 8 to 10 months (0 and $7 \mathrm{~d}$ shelf life), compared to RLOS (ULO and CA) and DCA-CF sampled peels (Figure 6a). Similarly, in the second season (2016), the 
accumulation of MHO was significantly higher after 6 and 8 months ( $7 \mathrm{~d}$ shelf life), and 10 months ( $0 \mathrm{~d}$ shelf life) for RA treated peels compared to RLOS (ULO and CA) and DCACF stored peels (Figure 6b). For both seasons (2015 and 2016), $\alpha$-farnesene content was significantly higher in RA treated peels after 6 months compared to RLOS (ULO and CA) and DCA-CF treatments (Figure 7a,b). During storage, $\alpha$-farnesene content was generally stable in peels sampled from RLOS (ULO and CA) and DCA-CF stored apple. On the contrary, in RA treated peels, $\alpha$-farnesene steadily increased, reaching its peak at around 6 months of storage and subsequently declining.

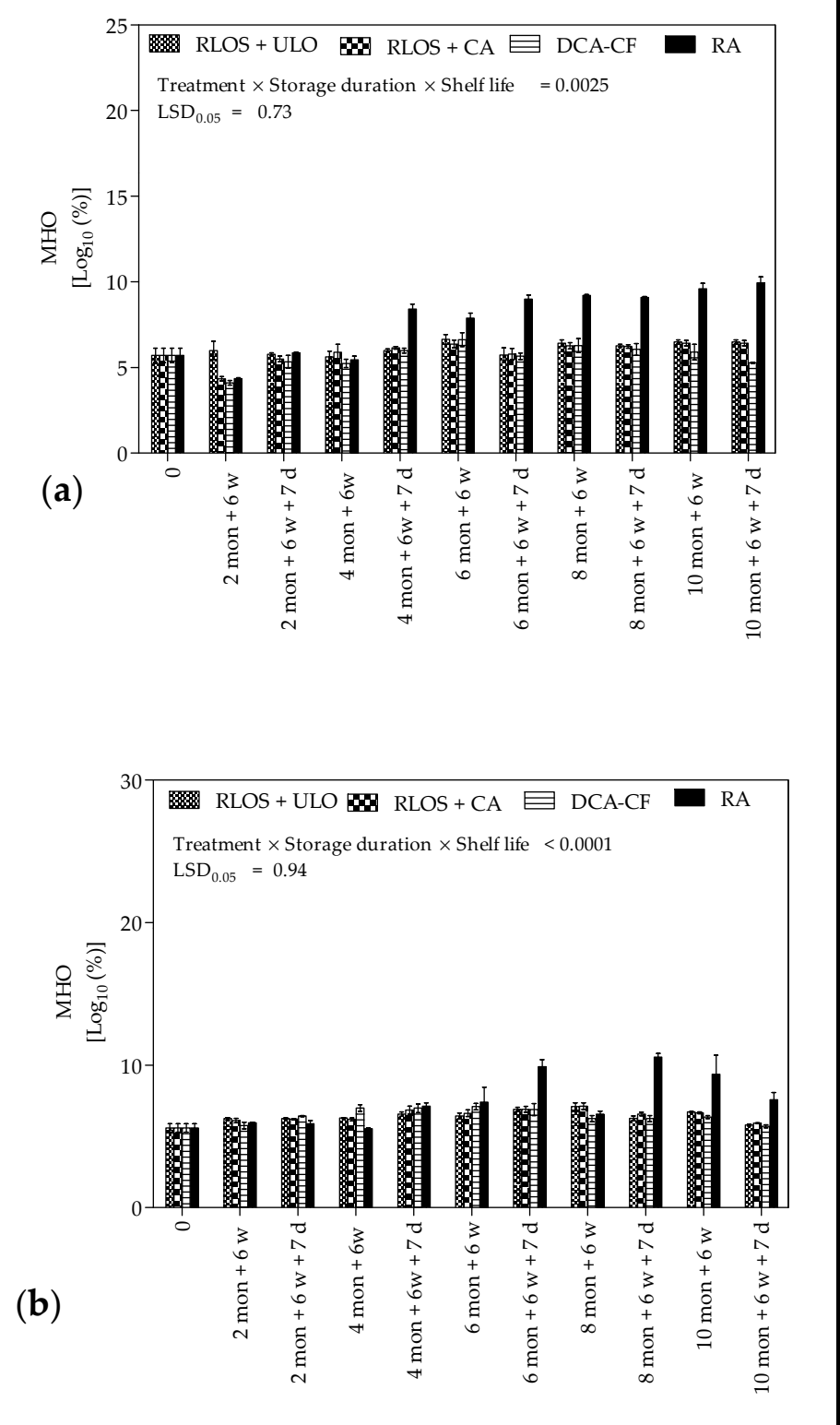

Figure 6. Accumulation of MHO (Log (\%)) of 'Granny Smith' apples harvested in the 2015 (a) and 2016 (b) seasons at commercial maturity and stored for up to 10 months at $0{ }^{\circ} \mathrm{C}$ in various storage conditions, evaluated every two months followed by a 6 week simulated shipment and handling period, and at 7 days on the shelf $\left(20^{\circ} \mathrm{C}\right.$ and $\left.65 \% \mathrm{RH}\right)$. Vertical bars represent the standard error (SE) of mean values of 3 replicates ( 1 replicate $=10$ fruit). $\mathrm{LSD}_{0.05}$ represents least significant difference $(p<0.05)$. For storage duration, mon-months; $w$-weeks; and $\mathrm{d}$-days. RLOS-repeated low oxygen stress; ULO-ultra-low oxygen; CA—controlled atmosphere; DCA-CF-dynamic controlled atmosphere-chlorophyll fluorescence; RA-regular atmosphere. 

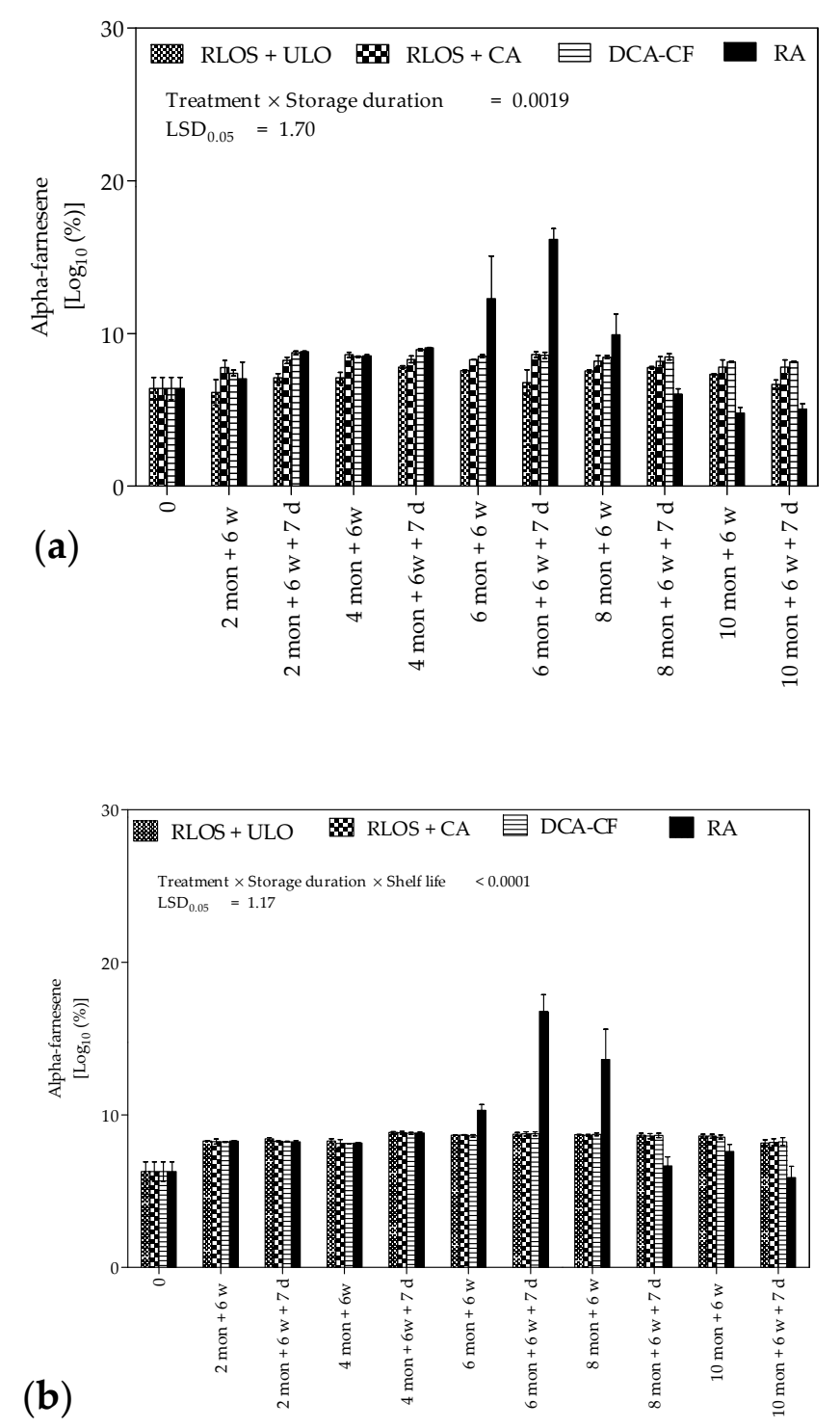

Figure 7. Alpha-farnesene (Log\% peak area) of 'Granny Smith' apples harvested in the 2015 (a) and 2016 (b) seasons at commercial maturity and stored for up to 10 months at $0{ }^{\circ} \mathrm{C}$ in various storage conditions, evaluated every two months followed by a 6 week simulated shipment and handling period, and at 7 days on the shelf $\left(20^{\circ} \mathrm{C}\right.$ and $\left.65 \% \mathrm{RH}\right)$. Vertical bars represent the standard error $(\mathrm{SE})$ of mean values of 3 replicates $\left(1\right.$ replicate $=10$ fruit). $\mathrm{LSD}_{0.05}$ represents least significant difference $(p<0.05)$. $\operatorname{LSD}_{0.05}$ represent least significant difference $(p<0.05)$. For storage duration, mon-months; w—week; and d-days. RLOS—repeated low oxygen stress; ULO-ultra-low oxygen; CA—controlled atmosphere; DCA-CF-dynamic controlled atmosphere-chlorophyll fluorescence; RA-regular atmosphere.

\subsection{Biochemical Analysis}

\subsubsection{Total Phenolic Content}

The changes in TPC are shown in Figure 8. There were minimal changes in TPC as storage duration was extended, with no clear difference between fruit stored using low oxygen technologies and RA (Figure 8a). However, TPC reached a maximum of $40.64 \pm 0.82 \mathrm{mg} \mathrm{GAE} / \mathrm{g}$ DM for apples stored in RLOS + CA after 6 months. The lowest TPC ( $38.75 \pm 0.06 \mathrm{mg} \mathrm{GAE} / \mathrm{g} \mathrm{DM})$ was recorded after 8 months for RA stored fruit. In the 2016 season (Figure 8b), at 6 months, TPC appeared to significantly decrease for RA stored 
apples compared to low oxygen technologies. Following that, all low oxygen technologies, except DCA-CF, maintained TPC higher than RA treatment.

\subsubsection{Radical Scavenging Activity}

In the 2015 season, significantly lower antioxidant activity in RA than in RLOS (ULO and CA) and DCA-CF sampled peels was recorded after 4, 8, and 10 months (Figure 9a). The RSA generally fluctuated during RLOS (ULO and CA) storage and DCA-CF treated peels, with no significant change. For RLOS (ULO and CA) and DCA-CF treated peels, there was no substantial difference in RSA between 0 and $7 \mathrm{~d}$ shelf life. As previously observed in the first harvest season (2015), RSA was stable for RLOS (ULO and CA) and DCA-CF treated peels in the 2016 season (Figure 9b). However, between 4 and 8 months of storage, a significant decrease in RSA was observed after $7 \mathrm{~d}$ shelf life for RA treated peels.

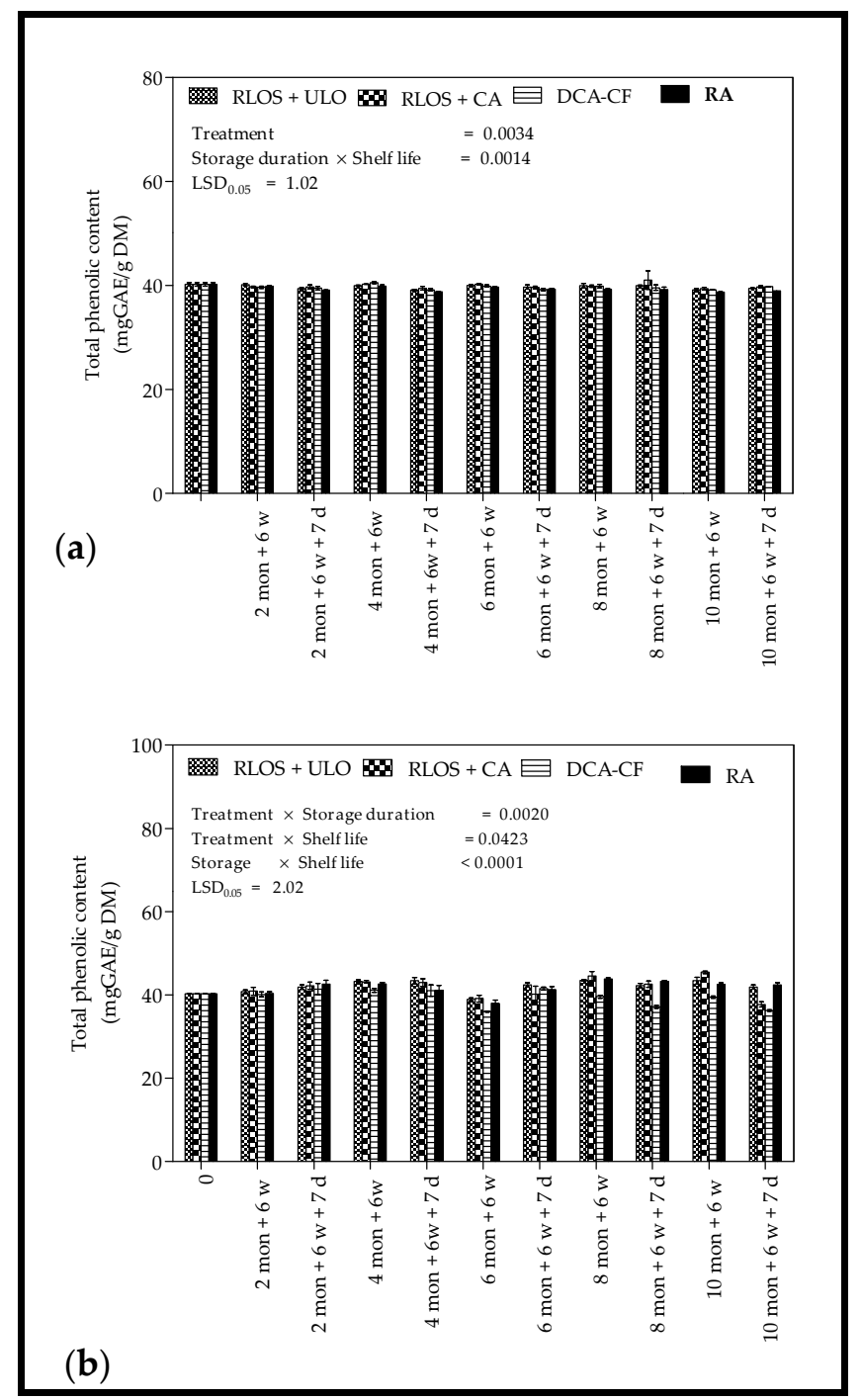

Figure 8. Total phenolic content (mgGAE/g DM) of 'Granny Smith' apples harvested in the 2015 (a) and 2016 (b) seasons at commercial maturity and stored for up to 10 months at $0^{\circ} \mathrm{C}$ in various storage conditions, evaluated every two months followed by a 6 week simulated shipment and handling period, and at 7 days on the shelf $\left(20^{\circ} \mathrm{C}\right.$ and $\left.65 \% \mathrm{RH}\right)$. Vertical bars represent the standard error (SE) of mean values of 3 replicates ( 1 replicate $=10$ fruit). $\mathrm{LSD}_{0.05}$ represents least significant difference $(p<0.05) . \mathrm{LSD}_{0.05}$ represent least significant difference $(p<0.05)$. For storage duration, monmonths; w-weeks; and d-days. RLOS—repeated low oxygen stress; ULO-ultra-low oxygen; CA-controlled atmosphere; DCA-CF-dynamic controlled atmosphere-chlorophyll fluorescence; RA-regular atmosphere. 


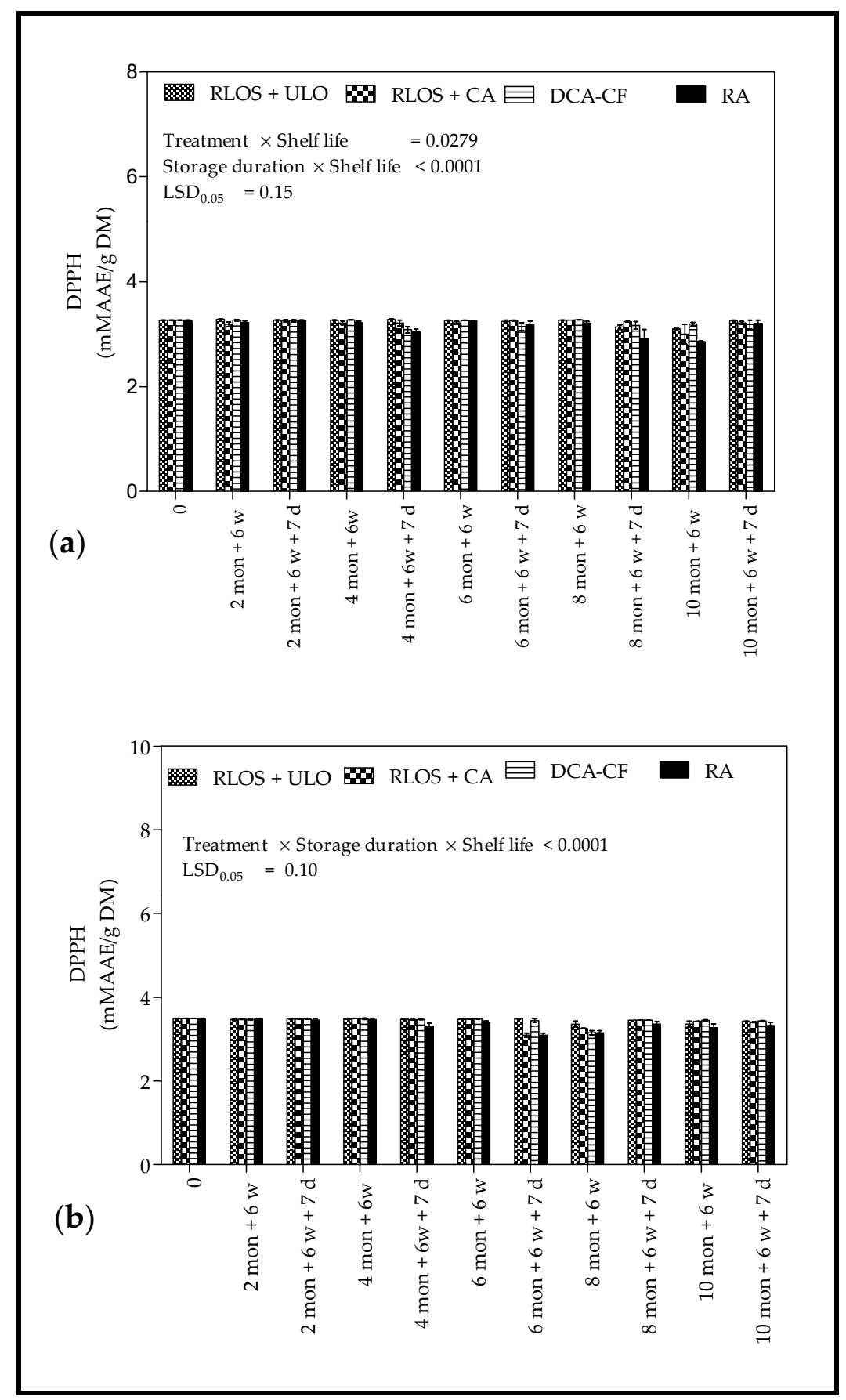

Figure 9. Radical scavenging activity (mgGAE/g DM) of 'Granny Smith' apples harvested in the 2015 (a) and 2016 (b) seasons at commercial maturity and stored for up to 10 months at $0{ }^{\circ} \mathrm{C}$ in various storage conditions, evaluated every two months followed by a 6 week simulated shipment and handling period, and at 7 days on the shelf $\left(20^{\circ} \mathrm{C}\right.$ and $\left.65 \% \mathrm{RH}\right)$. Vertical bars represents the standard error (SE) of mean values of 3 replicates $\left(1\right.$ replicate $=10$ fruit). $\mathrm{LSD}_{0.05}$ represent least significant difference $(p<0.05)$. For storage duration, mon-months; w-weeks; and d-days. RLOS—repeated low oxygen stress; ULO—ultra-low oxygen; CA—controlled atmosphere; DCA$\mathrm{CF}$-dynamic controlled atmosphere-chlorophyll fluorescence; RA—regular atmosphere.

\subsection{Correlation Analysis}

There was a positive correlation for superficial scald with $\mathrm{MHO}$ of $\mathrm{r}=0.66103$ $(p<0.0001)$. A negative correlation was detected between superficial scald and RSA and between superficial scald and TPC $(r=-0.30748$ and -0.3527 , respectively) (Table 3$)$. 
Table 3. Correlation of superficial scald and volatiles ( $\alpha$-farnesene and MHO), total phenolic content, and total antioxidant capacity.

\begin{tabular}{|c|c|c|c|c|c|c|c|c|c|c|}
\hline \multirow[b]{3}{*}{ Parameter } & \multicolumn{8}{|c|}{ Pearson's Correlation } & & \\
\hline & \multicolumn{2}{|c|}{ Superficial Scald } & \multicolumn{2}{|c|}{ MHO } & \multicolumn{2}{|c|}{$\alpha$-Farnesene } & \multicolumn{2}{|c|}{$\begin{array}{l}\text { Total Phenolic } \\
\text { Content }\end{array}$} & \multicolumn{2}{|c|}{$\begin{array}{c}\text { Radical Scavenging } \\
\text { Activity }\end{array}$} \\
\hline & $\mathbf{r}$ & $p$ & $\mathbf{r}$ & $p$ & $\mathbf{r}$ & $p$ & $\mathbf{r}$ & $p$ & $\mathbf{r}$ & $p$ \\
\hline 6 methyl-5-hepten-2-one & 0.6610 & $<0.0001$ & - & - & 0.2701 & $<0.0001$ & -0.2061 & $<0.0001$ & -0.2547 & $<0.0001$ \\
\hline$\alpha$-farnesene & 0.3187 & $<0.0001$ & 0.2701 & $<0.0001$ & - & - & - & NS * & - & NS \\
\hline Total phenolic content & -0.3527 & $<0.0001$ & -0.2061 & $<0.0001$ & - & NS & - & - & 0.4191 & $<0.0001$ \\
\hline Radical scavenging activity & -0.3048 & $<0.0001$ & -0.2545 & $<0.0001$ & - & NS & 0.4191 & $<0.0001$ & - & - \\
\hline
\end{tabular}

*: NS—no significant correlation between two parameters $(p \leq 0.05)$; - correlation coefficient; $p-p$ value at $95 \%$ confidence interval.

\section{Discussion}

\subsection{Physiological Disorders \\ 4.1.1. Superficial Scald}

In this study, the storage of 'Granny Smith' apples using RLOS + ULO, RLOS + CA, and DCA-CF treatments reduced the development of superficial scald compared with RA. Similarly, several studies have reported the reduction of superficial scald development on 'Granny Smith' apples by low oxygen storage technologies [2,3,9]. For instance, Mditshwa et al. [2] demonstrated that DCA-CF $\left(\mathrm{O}_{2}=0.3-0.5 \%\right.$ and $\left.\mathrm{CO}_{2}=1 \%\right)$ reduced superficial scald to $2 \%$ after 16 weeks of cold storage. Likewise, Poirier et al. [32] reported that, over two consecutive seasons, ULO $(\leq 1.0 \mathrm{kPa} \mathrm{O})$ phase applied before $\mathrm{CA}\left(0.5-1{ }^{\circ} \mathrm{C}\right.$ and $0.5-0.8 \mathrm{kPa} \mathrm{O} ;$; 0.5-0.6 $\mathrm{kPa} \mathrm{CO}_{2}$ ) storage controlled the development superficial scald on 'Granny Smith' apples. Studies have suggested that low oxygen technologies minimize the accumulation of ethylene, conjugated trienols, 6 methyl-5-hepten-2-one, and $\alpha$-farnesene in apple peel to reduce superficial incidence $[1,2,33]$.

The development of superficial scald symptoms is believed to be primarily driven by the oxidation processes of implicated volatiles such $\alpha$-farnesene, 6-methyl-5-hepten-2one, and others [4]. Therefore, storing 'Granny Smith' apples in low oxygen technologies such as RLOS + ULO, RLOS + CA, and DCA-CF is expected to reduce superficial scald development. The ULO $\left(0.9 \% \mathrm{O}_{2}\right.$ and $0.8 \% \mathrm{CO}_{2}$ for $21 \mathrm{~d}$ and $0.5 \% \mathrm{O}_{2}$ for $\left.7 \mathrm{~d}\right)$ phase exposes apples to lower oxygen concentration than the $\mathrm{CA}\left(1.5 \% \mathrm{O}_{2}\right.$ and $1 \% \mathrm{CO}_{2}$ for $21 \mathrm{~d}$ and $0.5 \%$ $\mathrm{O}_{2}$ for $7 \mathrm{~d}$ ); that is, $0.9 \% \mathrm{O}_{2}$ for ULO and $1.5 \% \mathrm{O}_{2}$ for CA. The assumption would be that the risk of superficial scald development would be higher in the CA phase than in the ULO phase because of the lower oxygen availability. However, in a season with a high risk of superficial scald development, other factors besides oxidation of implicated volatiles become more important, especially factors related to seasonal variations.

Critical factors that vary with harvest season, such as air temperature and light intensity, affect superficial scald susceptibility [4]. In 'Granny Smith', 'Cox's Orange', and 'Pacific Queen' apples, low mean air temperature and high light intensity during a growing season was associated with increased total phenolics and ascorbic acid content, which reduced the risk of superficial scald development [34]. A closer look at the results of apples stored using the RA treatment shows that the 2016 season appeared to have a higher risk of superficial scald than the 2015 season. In the 2016 season, superficial scald was detected earlier at 2 months +7 days, whereas in the 2015 season, it was observed after 4 months of cold storage. In the 2016 season, the detection of superficial scald in fruit stored using RLOS + ULO and DCA-CF suggests that other factors besides oxygen concentration may have been involved in the development of the physiological disorder. We speculate that these factors are linked to seasonal variation. The seasonal variation in the incidence and severity of superficial scald between the 2015 and 2016 seasons corroborates with previous studies conducted on 'Granny Smith' apples during cold storage [2,14].

\subsubsection{Coreflush}

Coreflush is a physiological disorder often described as a form of chilling injury affecting the quality of pome fruit $[35,36]$. The physiological disorder is often observed 
when apples are cut open as diffuse browning of cortex tissue adjacent to the carpels [37]. The mechanism of development of coreflush is not clearly understood. However, studies suggest that it is more prevalent in late harvested fruit and is induced by low temperature storage $[35,38]$. Prevention of coreflush incidence is achieved by slow cooling to $0{ }^{\circ} \mathrm{C}$, applying antioxidants before cold storage, and low ethylene storage [38]. In this study, fruit were not step-wise cooled before storage, which could have contributed to the development of coreflush. The results showed that low oxygen technologies were not effective in minimizing the development of coreflush in either harvest seasons.

\subsection{Physicochemical Properties}

\subsubsection{Flesh Firmness}

Loss of firmness is often associated with the ripening of apples during cold storage [24]. During storage, the tissue strength of apple peel decreases due to ripening associated processes such as enzyme mediated increase in soluble pectin, volume, and internal cell spaces and net loss of non-cellulosic sugars, galactose, and arabinose [39]. Based on the results, RLOS (ULO and CA) and DCA-CF treatments retarded the loss of flesh firmness during storage. Studies have found apples stored in low oxygen technologies to be more firm compared with fruit stored at RA $[40,41]$. Low oxygen technologies slow down ethylene production, respiratory metabolism, and tissue breakdown during the ripening processes, which reduces firmness loss [3,42].

\subsubsection{Background Color}

The pattern of change for color attribute $\mathrm{a}^{*}$ in the 2015 and 2016 seasons suggested that RLOS (ULO and CA) and DCA-CF treatments minimized the decrease in the green color of 'Granny Smith' apples. The results corroborate with Zanella [35], who observed minimal change in the green color of 'Granny Smith' apples stored using low oxygen $\left(0.4 \mathrm{kPa} \mathrm{O}_{2}\right)$ and $\mathrm{CA}\left(1.5 \mathrm{kPa} \mathrm{O}_{2}\right.$ and $1.3 \mathrm{kPaCO}$ ) compared with RA $\left(21 \mathrm{kPa} \mathrm{O}_{2}\right.$ and $\left.0.03 \mathrm{kPa} \mathrm{CO}_{2}\right)$. Likewise, studies by Mditshwa et al. [2] showed that repeated application of DCA-CF $\left(0.3-0.5 \% \mathrm{O}_{2}\right.$ and $\left.1 \% \mathrm{CO}_{2}\right)$ maintained the green color of 'Granny Smith' apples during cold storage $\left(0^{\circ} \mathrm{C}\right.$ and $\left.95 \% \mathrm{RH}\right)$.

Overall, RLOS (ULO and CA) and DCA-CF reduced $\mathrm{h}^{\circ}$ loss of 'Granny Smith' apples compared to RA, especially in the first harvest season (2015 season) when the risk of scald development was low. This indicates that low oxygen technologies resulted in fresher green color, while lower hue values denoted a more yellowish background color of apples subjected to RA storage. Similar results were reported for 'Granny Smith' apples and 'd'Anjou' pears subjected to low oxygen technologies such as ULO and DCA-CF during cold storage $[13,19,35]$, which limited the decrease in $h^{\circ}$ by possibly reducing chlorophyll breakdown due to leakage of organic acid from the vacuole, oxidative stress, and chlorophyllases [24].

\subsubsection{Total Soluble Solids and Titratable Acidity}

Overall, RLOS (ULO and CA) and DCA-CF maintained TSS content significantly higher than RA during long term storage. The results were in accordance with Rebeaud and Gasser [40], who reported higher TSS content in DCA-CF stored 'Golden Delicious' apples compared to RA stored fruit after 16 and $36 \mathrm{w}$ of cold storage. Titratable acidity content of 'Granny Smith' apples usually decreases as storage duration is extended [43]. The use of fruit organic acids in respiration during storage has been suggested as the cause for decreases in TA content [44-46]. The RLOS (ULO and CA) and DCA-CF treatments reduced the decline in TA as storage duration was extended whilst there was a general decrease in TA content during storage of RA treated fruit. These results agree with Mditshwa et al. [9], who reported that 'Granny Smith' apples stored in repeated DCA-CF had higher TA levels compared to RA stored fruit. Similarly, Lafer [47] reported that DCA-CF storage maintained firmness and TA content at higher levels for 'Uta' pears compared to standard CA. 


\subsection{Headspace Volatile Analysis}

The greater accumulation of MHO observed for RA treated peels compared to RLOS (ULO and CA) and DCA-CF stored apples was consistent with results reported by Mditshwa et al. [2] for 'Granny Smith' apple peels subjected to repeated DCA-CF storage for up to $6 \mathrm{w}$ at $-0.5{ }^{\circ} \mathrm{C}$ and $95 \%$ relative humidity (RH). Additionally, Ramokonyane [14] outlined that optimally harvested 'Granny Smith' apples stored in RA at $0{ }^{\circ} \mathrm{C}$ for up to 7 months had markedly higher $\mathrm{MHO}$ concentration compared to DCA-CF and CA, preceded by initial low oxygen stress (ILOS + CA) stored fruit. Studies have reported that superficial scald is related to the extent of $\alpha$-farnesene oxidation in susceptible apple cultivars [1,2]. Therefore, the accumulation $\alpha$-farnesene in apple peels is expected to vary with storage duration as oxidative products increase.

Alpha-farnesene was detected at harvest, which confirms that it is a naturally occurring volatile in 'Granny Smith' apples [4]. Accumulation of $\alpha$-farnesene in apple peel is reduced by low oxygen storage by applying anaerobic treatments, CA, or hypobaric storage [48,49]. Moreover, Sabban-Amin et al. [50] reported reduced $\alpha$-farnesene production for 'Granny Smith' apples subjected to $<0.5 \% \mathrm{O}_{2}$ followed by RA at $0{ }^{\circ} \mathrm{C}$ for $24 \mathrm{w}$. Likewise, Mditshwa et al. [2] observed substantially low $\alpha$-farnesene content for 'Granny Smith' apples subjected to repeated DCA-CF treatment with an intermittent RA period in comparison to RA stored fruit for 24-70 d storage. It is generally accepted that the concentration of $\alpha$-farnesene increases when apples are transferred into cold storage, particularly in RA, reaching a maximum between 8 and $12 \mathrm{w}$ and subsequently declining [51-53]. However, dynamic changes in $\alpha$-farnesene content in apple peel varies with storage temperature and atmosphere. For instance, Mditshwa [54] reported that $\alpha$-farnesene concentration in 'Granny Smith' apples was highest after 12 weeks of storage in RA at $0{ }^{\circ} \mathrm{C}$. This is contrary to Ramokonyane [14], who only observed significant differences in $\alpha$-farnesene concentration at shelf life and not during storage for 'Granny Smith' apples subjected to DCA-CF at $0{ }^{\circ} \mathrm{C}$. In this study, the delay in $\alpha$-farnesene accumulation could suggest suppression of oxidative processes in peels, particularly for RLOS (ULO and CA) and DCA-CF treatments. Subsequent decreases in $\alpha$-farnesene may also indicate the accumulation of $\mathrm{MHO}$, its oxidative product $[4,55]$.

\subsection{Biochemical Analysis}

\subsubsection{Total Phenolic Content}

Slight changes in TPC observed under all treatments during storage could be associated with the respiratory and ethylene climacteric in apple fruit, which initiates ripening, particularly for fruit subjected to RA storage regimes [4,9]. Research work has suggested that the production of phenolics in apple peel during storage is an ethylene-independent process, and phenolics exhibit an ethylene-dependent regulation when ethylene biosynthesis is suppressed [56]. The behavior of RLOS (ULO and CA) and DCA-CF treated peels resembles 1-MCP treated 'Granny Smith' apples, as reported by Shaham et al. [57], in which no significant decline in phenol concentration were observed when fruit was stored at $0{ }^{\circ} \mathrm{C}$. However, Leja et al. [58] observed a significant increase in total phenolics for 'Jonagold' and 'S'ampion' during cold storage at $1{ }^{\circ} \mathrm{C}$. Studies have demonstrated various patterns of change exhibited by phenolics during storage in several apple cultivars. For instance, Tarozzi et al. [59] reported that, during storage of 'Golden Delicious' apples at $0{ }^{\circ} \mathrm{C}$, total phenolic content decreased in fruit peels after 3 months of cold storage. However, Shaham et al. [57] did not observe a distinct pattern of change in phenolics during storage of optimally harvested 'Granny Smith' apples stored at $0{ }^{\circ} \mathrm{C}$ for up to $6 \mathrm{w}$ after pre-treatment with 1-MCP or heat. Golding et al. [8] reported that phenol concentration was generally stable, though simple phenols decreased in optimally harvested 'Granny Smith', 'Lady Williams', and 'Crofton' apples stored in air at $0{ }^{\circ} \mathrm{C}$ for 9 months. 


\subsubsection{Radical Scavenging Activity}

The effectiveness of low oxygen technologies to limit the decrease in total antioxidant capacity has been previously reported. For instance, Mditshwa et al. [9] observed higher RSA for optimally harvested 'Granny Smith' apples stored at $0{ }^{\circ} \mathrm{C}$ in DCA-CF compared to RA. The total antioxidant capacity of RLOS (ULO and CA) treated peels resembled the behavior of 1-MCP treated optimally harvested 'Granny Smith' apples according to Shaham et al. [57], who reported higher RSA in 1-MCP treated 'Granny Smith' apples compared to regular stored fruit. The trend in RSA change during storage in RA treated peels corroborates the findings of Barden and Bramlage [7], who observed that water soluble antioxidants decreased with an increase in storage duration of 'Cortland' and 'Delicious' apples stored at $0{ }^{\circ} \mathrm{C}$. In addition, Mditshwa et al. [9] reported inferior quality of optimally harvested 'Granny Smith' apples after storage in RA, which correlated with a decrease in RSA during storage. In contrast, RSA increased regardless of the storage conditions for optimally harvested 'Jonagold' and 'S'ampion' apples stored in CA $\left(2 \% \mathrm{CO}_{2}\right.$ and $2 \% \mathrm{O}_{2}$ ) and regular atmosphere for 120 days at $1{ }^{\circ} \mathrm{C}$ [58]. Based on the results, it can be argued that both RLOS (ULO and CA) and DCA-CF treatments inhibited the loss of RSA during storage and after $7 \mathrm{~d}$ shelf life in 'Granny Smith' apples.

\subsection{Correlation Analysis}

Negative correlations were found between superficial scald and both RSA and TPC, which may indicate minimal involvement of phenolic compounds in superficial scald induction. These results agree with Shaham et al. [57], who observed a fluctuation and little change in phenolic compound constitution and attributed the development of superficial scald to antioxidant enzyme activity. The accumulation of oxidative compounds of $\alpha$ farnesene and $\mathrm{MHO}$ has been associated with superficial scald induction [6,7]. However, in this study, correlation analysis suggested that other volatiles, such as conjugated trienols (CTols) and antioxidants (ascorbic acid and tocopherol), not quantified in this study, may be responsible for the development of superficial scald in 'Granny Smith' apples $[8,9,60]$.

\section{Conclusions}

This study showed that storing fruit under low oxygen controlled atmosphere technologies (RLOS and DCA-CF) at $0{ }^{\circ} \mathrm{C}$ can inhibit the development of superficial scald on 'Granny Smith' apples in a season of low superficial scald potential. Applying RLOS and DCA-CF maintained some internal quality parameters for up to 10 months of storage at $0{ }^{\circ} \mathrm{C}$ and after a simulated $6 \mathrm{w}$ of shipment and handling period plus $7 \mathrm{~d}$ shelf life $\left(20^{\circ} \mathrm{C}\right)$. This study demonstrated that both RLOS and DCA-CF inhibited superficial scald in 'Granny Smith' apples, possibly suppressing $\alpha$-farnesene oxidation. The results from this study confirmed the hypothesis that MHO causes superficial scald; however, other underlying mechanisms may have substantial contributions to the induction of superficial scald. This study also showed that RLOS and DCA-CF storage technologies maintain the antioxidant status of 'Granny Smith' apples, which is important in quality preservation. This study also highlighted that, while phenolic compounds possibly contribute to the inhibition of superficial incidence, their role varies significantly with harvest season. Further studies that focus on the emission of other volatiles such as conjugated trienes during storage, lipid peroxidation, and the relationship of superficial scald with other metabolites can elaborate more on the mechanism of action of RLOS technology. Additionally, the possibility of RLOS technology being used in combination with 1-MCP, currently applied on 'Granny Smith' apples, presents an innovative technology that could be investigated on 'Granny Smith' apples and other cultivars.

Author Contributions: Conceptualization, O.A.F. and U.L.O.; methodology, T.G.K., O.A.F., and U.L.O.; software, T.G.K. and O.A.F.; formal analysis, T.G.K. and O.A.F.; investigation, T.G.K.; resources, O.A.F. and U.L.O.; writing—original draft preparation, T.G.K., writing—review and editing, O.A.F. and U.L.O.; supervision, O.A.F. and U.L.O.; project administration, U.L.O. and O.A.F.; fund- 
ing acquisition, U.L.O. and O.A.F. All authors have read and agreed to the published version of the manuscript.

Funding: The authors are grateful to the Agricultural Research Council of South Africa, Postharvest Innovation Programme (PHI) and Hortgro Science for financial support.

Institutional Review Board Statement: Not applicable.

Informed Consent Statement: Not applicable.

Data Availability Statement: Restrictions apply to the availability of these data. Data are available from the authors with the permission of funder.

Acknowledgments: This work is based on the research supported wholly or in part by the National Research Foundation of South Africa (Grant Numbers: 64813). Research reported in this publication was supported in part by the Foundation for Food and Agriculture Research under award numberGrant ID: DFs-18-0000000008.

Conflicts of Interest: The opinions, findings and conclusions or recommendations expressed are those of the author(s) alone, and the NRF accepts no liability whatsoever in this regard.

\section{References}

1. Bordonaba, J.G.; Matthieu-Hurtiger, V.; Westercamp, P.; Coureau, C.; Dupille, E.; Larrigaudière, C. Dynamic changes in conjugated trienols during storage may be employed to predict superficial scald in 'Granny Smith' apples. LWT Food Sci. Technol. 2013, 54, 535-541. [CrossRef]

2. Mditshwa, A.; Fawole, O.A.; Vries, F.; van der Merwe, K.; Crouch, E.; Opara, U.L. Repeated application of dynamic controlled atmospheres reduced superficial scald incidence in 'Granny Smith' apples. Sci. Hortic. 2017, 220, 168-175. [CrossRef]

3. Mditshwa, A.; Fawole, O.A.; Opara, U.L. Recent developments on dynamic controlled atmosphere storage of apples-A review. Food Packag. Shelf Life 2018, 16, 59-68. [CrossRef]

4. Lurie, S.; Watkins, C.B. Superficial scald, its etiology and control. Postharvest Biol. Technol. 2012, 65, 44-60. [CrossRef]

5. Mditshwa, A.; Fawole, O.A.; Vries, F.; van der Merwe, K.; Crouch, E.; Opara, U.L. Classification of 'Granny Smith' apples with different levels of superficial scald severity based on targeted metabolites and discriminant analysis. J. Appl. Bot. Food Qual. 2016, $89,49-55$.

6. $\quad$ Rudell, D.R.; Mattheis, J.P.; Hertog, M.L. Metabolomic change precedes apple superficial scald symptoms. J. Agric. Food Chem. 2009, 57, 8459-8466. [CrossRef]

7. Barden, C.L.; Bramlage, W.J. Relationships of antioxidants in apple peel to changes in $\alpha$-farnesene and conjugated trienes during storage, and to superficial scald development after storage. Postharvest Biol. Technol. 1994, 4, 23-33. [CrossRef]

8. Golding, J.B.; McGlasson, W.B.; Wyllie, S.G. Relationship between production of ethylene and $\alpha$-farnesene in apples, and how it is influenced by the timing of diphenylamine treatment. Postharvest Biol. Technol. 2001, 21, 225-2533. [CrossRef]

9. Mditshwa, A.; Vries, F.; van der Merwe, K.; Crouch, E.; Opara, U.L. Antioxidant content and phytochemical properties of apple 'Granny Smith' at different harvest times. S. Afr. J. Plant Soil 2015, 32, 221-226. [CrossRef]

10. Zanella, A.; Stürz, S. Replacing DPA postharvest treatment by strategical application of novel storage technologies controls scald in 1/10th of EU's apples producing area. Acta Hortic. 2013, 1012, 419-426. [CrossRef]

11. Liu, Y.B. Ultralow oxygen treatment for postharvest control of western flower thrips, Frankliniella occidentalis (Thysanoptera: Thripidae), on iceberg lettuce. II. Effects of pre-treatment storage on lettuce quality. Postharvest Biol. Technol. 2008, 49, 135-139. [CrossRef]

12. Juhneviča-Radenkova, K.; Radenkovs, V. Influence of 1-Methylcyclopropene and ULO conditions on sensory characteristics of apple fruit grown in Latvia. J. Hortic. Res. 2016, 24, 37-46. [CrossRef]

13. Wang, Z.; Dilley, D.R. Initial low oxygen stress controls superficial scald of apples. Postharvest Biol. Technol. 2000, 18, 201-213. [CrossRef]

14. Ramokonyane, T.M. Effects of Dynamic Controlled Atmosphere and Initial Low Oxygen Stress on Superficial Scald of 'Granny Smith' Apples and 'Packham's Triumph' Pears. Master's Thesis, Stellenbosch University, Stellenbosch, South Africa, March 2016. Available online: https:/ / scholar.sun.ac.za/handle/10019.1/98327 (accessed on 20 January 2021).

15. Ghahramani, F.; Scott, K.J. Oxygen stress of 'Granny Smith' apples in relation to superficial scald, ethanol and alpha-farnesene, and conjugated trienes. Aust. J. Agric. Res. 1998, 49, 207-210. [CrossRef]

16. Chervin, C.; Brouard, L.; Frémondière, G.; Westercamp, P.; Thieffry, N.; Larrigaudiere, C. Superficial scald versus ethanol vapours: A dose response. Superficial scald versus ethanol vapours: A dose response. Acta Hortic. 2003, 600, 117-121. [CrossRef]

17. Wang, Z.; Dilley, D.R. Initial low oxygen stress (ILOS) controls scald of apples without using postharvest chemical treatments. Acta Hortic. 2001, 553, 261-266. [CrossRef]

18. Thewes, F.R.; Both, V.; Brackmann, A.; Weber, A.; de Oliveira Anese, R. Dynamic controlled atmosphere and ultralow oxygen storage on 'Gala' mutants quality maintenance. Food Chem. 2015, 188, 62-70. [CrossRef] 
19. Erkan, M.; Pekmezc, M.; Gübbük, H.; Karafiah, I. Effects of controlled atmosphere storage on scald development and postharvest physiology of 'Granny Smith' Apples. Turk. J. Agric. 2004, 28, 43-48.

20. Tran, D.T.; Verlinden, B.E.; Hertog, M.; Nicolaï, B.M. Monitoring of extremely low oxygen control atmosphere storage of 'Greenstar' apples using chlorophyll fluorescence. Sci. Hortic. 2015, 184, 18-22. [CrossRef]

21. Prange, R.K.; Wright, A.H.; DeLong, J.M.; Zanella, A. A review on the successful adoption of dynamic controlled-atmosphere (DCA) storage as a replacement for diphenylamine (DPA), the chemical used for control of superficial scald in apples and pears. Acta Hortic. 2015, 1071, 389-396. [CrossRef]

22. Weber, A.; Brackmann, A.; Both, V.; Pavanello, E.P.; de Oliveira Anese, R.; Thewes, F.R.; Anese, R.D.O.; Rodrigo, F. Respiratory quotient: Innovative method for monitoring 'Royal Gala' apple storage in a dynamic controlled atmosphere. Sci. Agric. 2015, 72, 28-33. [CrossRef]

23. Feng, F.; Li, M.; Ma, F.; Cheng, L. Effects of location within the tree canopy on carbohydrates, organic acids, amino acids and phenolic compounds in the fruit peel and flesh from three apple (Malus $\times$ domestica) cultivars. Hortic. Res. 2014, 1, 1-7. [CrossRef]

24. Bessemans, N.; Verboven, P.; Verlinden, B.E.; Nicolaï, B.M. A novel type of dynamic controlled atmosphere storage based on the respiratory quotient (RQ-DCA). Postharvest Biol. Technol. 2016, 115, 91-102. [CrossRef]

25. Wright, A.H.; DeLong, J.M.; Gunawardena, A.H.; Prange, R.K. The interrelationship between the lower oxygen limit, chlorophyll fluorescence and the xanthophyll cycle in plants. Photosynth. Res. 2011, 107, 223-235. [CrossRef] [PubMed]

26. Veltman, R.H.; Verschoor, J.A.; van Dugteren, J.H.R. Dynamic control system (DCS) for apples (Malus domestica Borkh. cv 'Elstar'): Optimal quality through storage based on product response. Postharvest Biol. Technol. 2003, 27, 79-86. [CrossRef]

27. Watkins, C.B.; Bramlage, W.J.; Cregoe, B.A. Superficial scald of 'Granny Smith' apples is expressed as a typical chilling injury. J. Am. Soc. Hortic. Sci. 1995, 120, 88-94. [CrossRef]

28. Chen, L.; Opara, U.L. Texture measurement approaches in fresh and processed foods-A review. Food Res. Int. 2013, 51, 823-835. [CrossRef]

29. Hussein, Z.; Fawole, O.A.; Opara, U.O. Effects of bruising and storage duration on physiological response and quality attributes of pomegranate fruit. Sci. Hortic. 2020, 267, 1-7. [CrossRef]

30. Al-Said, F.A.; Opara, L.U.; Al-Yahyai, R.A. Physico-chemical and textural quality attributes of pomegranate cultivars (Punica granatum L.) grown in the Sultanate of Oman. J. Food Eng. 2009, 90, 129-134. [CrossRef]

31. Mayuoni-Kirshinbaum, L.; Daus, A.; Porat, R. Changes in sensory quality and aroma volatile composition during prolonged storage of 'Wonderful' pomegranate fruit. Int. J. Food Sci. Technol. 2013, 48, 1569-1578. [CrossRef]

32. Poirier, B.C.; Mattheis, J.P.; Rudell, D.R. Extending 'Granny Smith' apple superficial scald control following long-term ultra-low oxygen controlled atmosphere storage. Postharvest Biol. Technol. 2020, 161, 111062. [CrossRef]

33. Lavilla, T.; Puy, J.; López, M.L.; Recasens, I.; Vendrell, M. Relationships between volatile production, fruit quality, and sensory evaluation in Granny Smith apples stored in different controlled-atmosphere treatments by means of multivariate analysis J. Agric. Food Chem. 1999, 47, 3791-3803. [CrossRef] [PubMed]

34. McGhie, T.K.; Hunt, M.; Barnett, L.E. Cultivar and growing region determine the antioxidant polyphenolic concentration and composition of apples grown in New Zealand. J. Agric. Food Chem. 2005, 53, 3065-3070. [CrossRef]

35. Zanella, A. Control of apple superficial scald and ripening-A comparison between 1-methylcyclopropene and diphenylamine postharvest treatments, initial low oxygen stress and ultra-low oxygen storage. Postharvest Biol. Technol. 2003, 27, 69-78. [CrossRef]

36. Ju, Z.; Curry, E.A. Stripped corn oil emulsion alters ripening, reduces superficial scald, and reduces core flush in 'Granny Smith' apples and decay in 'd' Anjou' pears. Postharvest Biol. Technol. 2000, 20, 185-193. [CrossRef]

37. Johnson, D.S.; Colgan, R.J. Low ethylene controlled atmosphere induces adverse effects on the quality of 'Cox's Orange Pippin' apples treated with aminoethoxyvinylglycine during fruit development. Postharvest Biol. Technol. 2003, 27, 59-68. [CrossRef]

38. Fan, X.; Mattheis, J.P.; Blankenship, S. Development of apple superficial scald, soft scald, core flush, and greasiness is reduced by MCP. J. Agric. Food Chem. 1999, 47, 3063-3068. [CrossRef]

39. De Ell, J.R.; Khanizadeh, S.; Saad, F.; Ferree, D.C. Factors affecting apple fruit firmness-A review. J. Am. Pomol. Soc. 2001, 55, $8-27$.

40. Rebeaud, S.G.; Gasser, F. Fruit quality as affected by 1-MCP treatment and DCA storage-A comparison of the two methods. Eur. J. Hortic. Sci. 2015, 80, 18-24. [CrossRef]

41. Zanella, A.; Rossi, O. Post-harvest retention of apple fruit firmness by 1-methylcyclopropene (1-MCP) treatment or dynamic CA storage with chlorophyll fluorescence (DCA-CF). Eur. J. Hortic. Sci. 2015, 80, 11-17. [CrossRef]

42. Graell, J.; Larrigaudiere, C.; Vendrell, M. Effect of low-oxygen atmospheres on quality and superficial scald of 'Top red' apples. Food Sci. Technol. Int. 1997, 3, 203-211. [CrossRef]

43. Magazin, N.; Keserović, Z.; Milić, B.; Dorić, M. Fruits quality of granny smith apples treated with 1- methylcyclopropene or diphenylamine and stored under ulo conditions. Acta Hortic. 2013, 981, 619-624. [CrossRef]

44. Ding, C.K.; Chachin, K.; Hamauzu, Y.; Ueda, Y.; Imahori, Y. Effects of storage temperatures on physiology and quality of loquat fruit. Postharvest Biol. Technol. 1998, 14, 309-315. [CrossRef]

45. Melgarejo, P.; Salazar, D.M.; Artes, F. Organic acids and sugars composition of harvested pomegranate fruits. Eur. Food Res. Technol. 2000, 211, 185-190. [CrossRef] 
46. Both, V.; Thewes, F.R.; Brackmann, A.; de Freitas Ferreira, D.; Pavanello, E.P.; Wagner, R. Effect of low oxygen conditioning and ultralow oxygen storage on the volatile profile, ethylene production and respiration rate of 'Royal Gala' apples. Sci. Hortic. 2016, 209, 156-164. [CrossRef]

47. Lafer, G. Effect of different CA storage conditions on storability and fruit quality of organically grown 'Uta' pears. Acta Hortic. 2011, 909, 757-760. [CrossRef]

48. Matich, A.J.; Banks, N.H.; Rowan, D.D. Modification of $\alpha$-farnesene levels in cool-stored 'Granny Smith' apples by ventilation. Postharvest Biol. Technol. 1998, 14, 159-170. [CrossRef]

49. Rupasinghe, H.P.V.; Paliyath, G.; Murr, D.P. Biosynthesis of alpha-farnesene and its relation to superficial scald development in 'Delicious' apples. J. Am. Soc. Hort. Sci. 1998, 123, 882-886. [CrossRef]

50. Sabban-Amin, R.; Feygenberg, O.; Belausov, E.; Pesis, E. Low oxygen and 1-MCP pretreatments delay superficial scald development by reducing reactive oxygen species (ROS) accumulation in stored 'Granny Smith' apples. Postharvest Biol. Technol. 2011, 62, 295-304. [CrossRef]

51. Anet, E.F.L.J. Superficial scald, a functional disorder of stored apples. XI. Apple antioxidants. J. Sci. Food Agric. 1974, 25, $299-304$. [CrossRef]

52. Huelin, F.E.; Coggiola, I.M. Superficial scald, a functional disorder of stored apples. IV. Effect of variety, maturity, oiled wraps and diphenylamine on the concentration of alpha-farnesene in the fruit. J. Sci. Food Agric. 1968, 19, 297-301. [CrossRef] [PubMed]

53. Whitaker, B.D.; Villalobos-Acuña, M.; Mitcham, E.J.; Mattheis, J.P. Superficial scald susceptibility and alpha-farnesene metabolism in 'Bartlett' pears grown in California and Washington. Postharvest Biol. Technol. 2009, 53, 43-50. [CrossRef]

54. Mditshwa, A. The Potential of Dynamic Controlled Atmospheres and Possible Mechanisms in Mitigating Superficial Scald in Apples cv. 'Granny Smith'. Ph.D. Thesis, Stellenbosch University, Stellenbosch, South Africa, December 2015. Available online: https: / / scholar.sun.ac.za/handle/10019.1/97690 (accessed on 20 January 2021).

55. Anet, E.F.L.J.; Coggiola, I.M. Superficial scald, a functional disorder of stored apples. X. Control of alpha-farnesene autoxidation. J. Sci. Food Agric. 1974, 25, 293-298. [CrossRef]

56. Defilippi, B.G.; Dandekar, A.M.; Kader, A.A. Impact of suppression of ethylene action or biosynthesis on flavor metabolites in apple (Malus domestica Borkh) Fruits. J. Agric. Food Chem. 2004, 52, 5694-5701. [CrossRef]

57. Shaham, Z.; Lers, A.; Lurie, S. Effect of heat or 1-methylcyclopropene on antioxidative enzyme activities and antioxidants in apples in relation to superficial scald development. J. Amer. Soc. Hort. Sci. 2003, 128, 761-766. [CrossRef]

58. Leja, M.; Mareczek, A.; Ben, J. Antioxidant properties of two apple cultivars during long-term storage. Food Chem. 2003, 80, 303-307. [CrossRef]

59. Tarozzi, A.; Marchesi, A.; Cantelli-forti, G.; Hrelia, P. Cold-storage affects antioxidant properties of apples in Caco-2 cells. J. Nutr. 2004, 134, 1105-1109. [CrossRef]

60. Ahn, T.; Paliyath, G.; Murr, D.P. Antioxidant enzyme activities in apple varieties and resistance to superficial scald development. Food Res. Int. 2007, 40, 1012-1019. [CrossRef] 